IZA DP No. 8986

IC Technology and Learning:

An Impact Evaluation of Cl@ssi2.0

Daniele Checchi

Enrico Rettore

Silvia Girardi

April 2015 


\title{
IC Technology and Learning: An Impact Evaluation of Cl@ssi2.0
}

\author{
Daniele Checchi \\ FBK-Irvapp, University of Milan \\ and IZA \\ Enrico Rettore \\ FBK-Irvapp, University of Padua \\ and IZA
}

\section{Silvia Girardi}

FBK-Irvapp

\section{Discussion Paper No. 8986 \\ April 2015}

IZA

P.O. Box 7240

53072 Bonn

Germany

\author{
Phone: +49-228-3894-0 \\ Fax: +49-228-3894-180 \\ E-mail: iza@iza.org
}

\begin{abstract}
Any opinions expressed here are those of the author(s) and not those of IZA. Research published in this series may include views on policy, but the institute itself takes no institutional policy positions. The IZA research network is committed to the IZA Guiding Principles of Research Integrity.

The Institute for the Study of Labor (IZA) in Bonn is a local and virtual international research center and a place of communication between science, politics and business. IZA is an independent nonprofit organization supported by Deutsche Post Foundation. The center is associated with the University of Bonn and offers a stimulating research environment through its international network, workshops and conferences, data service, project support, research visits and doctoral program. IZA engages in (i) original and internationally competitive research in all fields of labor economics, (ii) development of policy concepts, and (iii) dissemination of research results and concepts to the interested public.
\end{abstract}

IZA Discussion Papers often represent preliminary work and are circulated to encourage discussion. Citation of such a paper should account for its provisional character. A revised version may be available directly from the author. 


\begin{abstract}
IC Technology and Learning: An Impact Evaluation of Cl@ssi2.0*

In this paper we present a counterfactual evaluation of the effect of ICT resources at school on student achievements conducted in Italy. In 2009156 classes at $6^{\text {th }}$ grade were endowed with additional resources earmarked for purchasing ICT equipments only. By selecting an equivalent number of classes in the same schools we are able to conduct an evaluation of the causal effect of ICT on student achievements, controlling for their initial level. Despite a significant financial investment (in the order of 1500 Euros per student over a three year period), results are very small: if we take the most encouraging results, the average improvement associated to the programme would be 3 test points, corresponding to $17 \%$ of a standard deviation. Even if it might be argued that our estimate represents a lower bound for the real effect, overall we conclude that the intervention has been far from being cost effective.
\end{abstract}

JEL Classification: $\quad$ 120, 128

Keywords: ICT, learning, randomised experiments

Corresponding author:

Daniele Checchi

FBK-Irvapp

Via Santa Croce 77

38122 Trento

Italy

E-mail: dchecchi@irvapp.it

\footnotetext{
Paper presented at SREE 2013 Spring conference (Washington). Fondazione Agnelli and Fondazione per la Scuola have generously funded the evaluation presented in this paper; Invalsi, the national agency for school assessment made the data on students' tests available to us. Many people have made this evaluation possible, and we would like to thank them all. In addition we would also thank people that at various stages of the research have helped us: Andrea Gavosto, Stefano Molina, Marco Giovannini and Gianfranco De Simone (Fondazione Agnelli); Annamaria Poggi and Claudia Mandrile (Fondazione per la Scuola); Piero Cipollone, Paolo Sestito, Roberto Ricci and Patrizia Falzetti (Invalsi); Gianna Barbieri and Antonio Martino (Ufficio Statistico del MIUR); Vittorio Campione and Filomena Morgia (Ufficio del Consigliere per le Tecnologie), Antonio Ronca, Giusy Cannella e Samuele Borri (Ansas). Eventually also Franco DeAnna, Valeria Pandolfini and Valentina Rastelli have provided valuable support at some stage of the research.
} 
Such research on the impact of ICT is evidence-based and seeks to establish a causal relationship between input and impact. This is the 'holy grail' of government in many countries of course but it is not easy to isolate cause from effect, especially in education where there are so many variables in play. (Balanskat et al 2006, p.23)

Jennifer Greene has stated that impact evaluation is 'inherently undemocratic'. What I take this to mean is that the way in which such studies are conducted and utilized is not very participatory. The approach to most impact evaluation studies is what Robert Chambers calls 'extractive' - that is, the researchers go and collect the data, scurry back to their ivory tower to analyse it, publish their article and move on. In contrast 'empowering' research takes place within the community, allowing them to define its parameters, take part in the analysis, so by deepening their understanding of their situation they are able to overcome obstacles, with research findings reinforcing this effort. A literal interpretation of this approach, running Stata classes in the African bush, is clearly nonsense. (White 2010, p.153)

\section{Introduction}

The introduction of IC technologies within schools may have significant repercussions in teaching. For example Balanskat et al. (2006) offer a review of 25 studies existing in the European context at that date. However the limited number of experimental studies makes it difficult to reach consensus on the causal impact of this technology, not to speak of the channels through which this is achieved. Several aspects contribute to the lack of a shared view. First of all, the standard requirements for proper randomised trials are rarely satisfied, since teachers and students spontaneously react to the non-contamination principle: schools are living bodies, and any novelty tends to be shared with mates. Second, different teaching contents are differently adaptable to computerised technologies, mainly because they do require different learning strategies. Consequently, in the same class some subjects may exhibit significant improvements in achievements while others remain unaffected. Third, the access to new technologies is heterogeneous across pupils, being correlated to the availability of analogous resources at home. All taken into account, it is not surprising to find different result in the (limited) literature existing on the topic.

In this paper we present empirical evidence on an specific experiment conducted in Italy on 156 lower secondary schools (grades 6 to 8), where a significant amount of money (30k Euros) were earmarked for ICT acquisition to the benefit of a single class (20-25 pupils) within the school. We match the 156 treated classes to an equivalent number of control classes within the same school and analyse the potential effect of a massive injection of ICT onto student achievement, measured by literacy and numeracy tests (taken at the entrance and three years later at the exit of lower secondary school). We find no effect of the treatment at the mean of the distribution, but some positive effects in the lower tail. The paper is organised as follows: the next section contains a literature review, while the third section presents our evaluation design. The fourth section introduces the proper counterfactual analysis, while the fifth concludes.

\section{Literature review}

The potential consequences of computer-aided teaching and/or learning are increasingly investigated. Balanskat et al. (2006) review distinguishes between assessments and impact evaluations, on two main areas: learning outcomes and learners on one side, and teaching methodologies and teachers on the other. Their overall account suggests positive effects on learning in primary school (more in home language and science, less compelling in mathematics), though part of these qualitative effects are drawn from teachers and/or parent perceptions. In this 
perspective, the vast majority of teachers record an increase in attention and motivation. ${ }^{1}$ On the teacher side, there are indications of increased enthusiasm and motivation; at a deeper level, there is also perception of a changing role in connection with the students. ${ }^{2}$

There is an increasing literature reporting local experiments of randomised supply of home computers to students accompanied by assessment of the effects on learning. For example Fairlie and Robinson (2013) evaluate the outcome of a field experiment involving the provision of free computers to low-income schoolchildren (between grade 6 and 10) for home use in California. Possibly because of the recorded increase in computer hours spent on games and social networks, they find no evidence that the home computers improved educational outcomes for the treatment group. Similarly Beuermann et alt. (2013) account for the impact of distributing home computers to primary school children in Peru (plan OLPC-one laptop per child). While their focus was on estimating spill-over effects through friendship networks (indirect effects), they find increased use of home computers, with some substitution away from computer use outside the home. Beneficiaries are more likely to complete domestic chores but less likely to read books. However the overall average effect on test scores is found to be nil.

Likewise Fairlie and London (2012) analyse the impact of free supply of computers for home use to low-income students attending community colleges in Northern California. They find a weakly positive effect on the two year following career of being selected for receiving a computer (intention to treat), even taking into account the fact that a fraction of non winner bought a new computer during the following two years of observation period. They rationalise these effects on the ground of increased flexibility in time use, showing that the effect is increasing in the distance from the campus (which represents the best alternative for computer use).

Stronger positive effects are found when computers are distributed to schools, in some cases also allowing children to bring computers at home after class hours. While originally Angrist and Lavy (2002) did not find statistically significant effects of computer-aided instruction (which requires the expansion of computer availability in classes) onto student test scores, Barrow et al (2009) produced evidence that the introduction of instructional computer software was effective in raising the algebraic skills. In the same vein Machin et al. (2007) found that random changes of ICT funding across schools produces an improvement in primary school achievements in literacy (but not in numeracy). Counterintuitive results are found in Vigdor and Ladd (2010) who show that using across-ZIP code variation in the timing of the introduction of high-speed internet service, the introduction of home computer technology is associated to modest but statistically significant and persistent negative impacts on student math and reading test scores, which they interpret as the outcome of widening achievement gaps by socio-economic status.

When considering developing countries, Barrera-Osorio et al. (2009) did not find effect on student test scores of randomised distribution of free computers to schools in Colombia, accompanied by teacher training. Using teachers and student surveys, they argue that the lack of impact is attributable to the failure to incorporate the computers into the educational process. Similarly Cristia et al. (2012) do not find significant effect on literacy and numeracy achievements of the One Laptop per Child (OLPC) among randomly selected primary schools in (rural) Peru. ${ }^{3}$ Ferrando et al. (2012)

\footnotetext{
1 "ICT has a strong motivational effect and positive effect on behaviour, communication and process skills" (p.4)). In addition, they suggest that ICT allows for greater responsibility of individual learning, as well as it eases team working: "ICT use at schools can help to minimise the social divide by reducing the digital divide" (p.4).

2 “...with ICT, the teacher tend to become more of an advisor, critical dialogue partner and leader for specific subject domains" (p.5)

${ }^{3}$ They find positive effect on general cognitive skills, which they attribute to non pedagogical activities: "information from computer logs indicates that a substantial share of laptop use was directed to activities that might have little effect on educational outcomes (word processing, calculator, games, music and recording sound and video)." (pg.6).
} 
consider the randomised distribution of computers to schools in Uruguay (Plan Ceibal), finding a positive impact on math test score of $6^{\text {th }}$ graders. ${ }^{4}$

Moving from increased availability of computers to increased availability of internet access does not help to shed light on the issue of potential causal impact of ICT: Goolsbee and Guryan (2006) studies the impact of public subsidy on school demand for internet connection, finding a significant elasticity, without any detectable spill-over effect of student tests. On the contrary, Hyland et al (2013) find that government programme providing broadband access to primary schools in Ireland is associated with higher average mathematics scores on standardised tests.

Even if we restrict our analysis to computer use in schools, we do not identify a consensual view on the impact of computer in student learning, for the number of factors to be held under control is large. Previous papers differ in

a) pre-existing conditions (diffusion of ICT technologies - and more specifically computers and internet connections - at school as well as at home);

b) availability of computers (for teachers and/or for students);

c) availability of teaching software;

d) availability of teacher training;

e) availability of internet connections.

These dimensions can be considered as educational production inputs, which are likely being characterised by partial complementarity. Since no paper can control all inputs at the same time, it is rather likely that finding (or not finding) statistically significant effect may depend on the joint variations of more than one input at the same time. We should also not neglect that self-selection into computer use by schools and/or by school averages makes any estimate of impact potentially biased.

In the present paper it is easier to isolate potential channels of influence, since others were prevented by design. As it will be clearer in the next paragraph, the additional funding was restricted to acquisition of hardware for students and/or teachers (thus purposely excluding teachers support and training, software and internet connection, which were pre-conditions for applying for funds). On the other hand, a weakness of this intervention relies in the possibility of acquisition of any IC technology, introducing heterogeneity of the treatment.

The other relevant feature one should keep in mind to interpret the results is the nationwide context of limited familiarity with IC technology. In facts, despite being high in the GDP per capita rankings, Italy is characterised by limited diffusion of ICT, both at home and in schools. According to TIMSS 2007 database (reported in Eurydice 2011) the percentage of $4^{\text {th }}$ graders using computers at school was $63 \%$ (60\% for $8^{\text {th }}$ graders), while corresponding figures for UK students are $86 \%$ and $79 \%$. When corresponding teachers were asked whether they had ever used a computer in science classes, $40 \%$ of Italian teachers in $4^{\text {th }}$ grade (and between $58 \%$ and $63 \%$ in $8^{\text {th }}$ grade) provided a negative answer (corresponding figures for UK teachers are lower by at least 20 points). Thus by the time of the experiment, Italy was a country with large margins for expanding the use of ICT in teaching.

\section{The Cl@ssi 2.0 program and the design of the impact evaluation}

Cl@ssi2.0 is a line of intervention launched in 2008 by the Italian Ministry of Education to foster ICT adoption in teaching. It is a large scale experiment, meant to modify learning environment and to diffuse new teaching experiences. It provided a large grant to buy ICT to 156 Italian classes at

\footnotetext{
${ }^{4}$ However their research design is not fully convincing, since they aim to exploit time lags in the implementation across various regions of the country, but treated and controls are not fully comparable.
} 
the beginning of $6^{\text {th }}$ grade (the initial year of junior high school) they make use of up to the end of $8^{\text {th }}$ grade (the final year of junior high school). The experiment was repeated at a lower scale in primary and upper secondary school in subsequent years, and then abandoned because high costs and lack of evidence on being effective.

In 2008 a call was sent to all Italian lower secondary schools. Conditions for eligibility of the school were the presence of broad-band connection, the internal approval of a project leaded by a certified ICT-trained teacher under a permanent contract. The projects were referred to a specific class within the school. 2361 schools reacted to the call and applied, and 156 of them (corresponding to the funds availability) were selected, respecting a regional stratification.

Schools within which treated classes has been chosen were not randomly selected by the 20 regional committees. We could not gain access to the minutes of the selection process but there is evidence that the selected schools are not representative of the pool of applicant schools (see below some evidence supporting this view). At the beginning of the following school year 2009/10 the classes identified by the 156 selected schools were entitled to receive an amount of 30.000 Euros (approximately 40.000 US dollars) to be spent in IC technology only (training and maintenance expenses were not admissible). The size of the grant is far from negligible to most of the schools included in the program (the median value of the grant as a proportion of total yearly resources available to the school is about $10 \%$ ).

According to the original protocol, researchers in the field of education from local universities were in charge of coaching the selected classes to develop new teaching practices. In practice, some classes in few regions received the visit of university researchers, but field surveys we conducted over the three year periods indicate that most of the sampled classed did not receive external supervision. ${ }^{5}$

Thanks to the support of two private foundations (Fondazione Giovanni Agnelli and Fondazione per la scuola) we ran an impact evaluation of the program. A control group has been defined as made up of one additional class in each school selected into the project. The school principals were required to identify as control classes those as similar as possible to the classes receiving the funding ("choose the second class you would have chosen, had the first not been chosen"). The only alternative strategy we could envisage was selecting control classes in schools not involved in the Cl@ssi 2.0 program (for example not applying to the call, or not selected despite having applied). Both strategies have pros and cons. The strategy of having treated and control classes in the same school is prone to the risk of contamination: control classes might gain some benefits from the ICT bought by the treatment classes, something that by design could not happen following the latter strategy. On the other hand, the latter strategy is likely to incur in a severe selection bias problem driven by student sorting across schools by social origins, a problem unlikely to be properly dealt with conditioning only on the bunch of school and student characteristics we were able to collect at the benchmark survey. On balance, we deemed that selecting controls in the same schools as treatment units was the best choice. At the same time we explicitly included in the monitoring system on the implementation of the program some tools to detect the possible contamination of the comparison group.

A benchmark survey has been run during 2009 fall collecting information on the students' socioeconomic background and a competence-based test to measure literacy and numeracy of all students included in the study to check the degree of comparability of treatment and comparison groups.

\footnotetext{
${ }^{5}$ As indirect evidence of our claim, we could not find any scientific article published out of this experience in pedagogical journals.
} 
Table 1 presents the results. ${ }^{6}$ The average score is marginally higher in the treated classes both for literacy and for numeracy. After conditioning on the observable socio-economic background of the student these differences decrease (see below). Note also that both treated and control classes feature an average score much larger than the national average score confirming that schools included in $\mathrm{Cl} @$ ssi 2.0 are by no means representative of the population of Italian schools.

Table 1: Test score in grade 6 - beginning of school year 2009-10

\begin{tabular}{|c|c|c|c|c|c|c|c|}
\hline & schools & Classes & students & $\begin{array}{l}\text { literacy } \\
\text { (mean) }\end{array}$ & $\begin{array}{l}\text { literacy } \\
\text { (sd) }\end{array}$ & $\begin{array}{l}\text { numeracy } \\
\text { (mean) }\end{array}$ & $\begin{array}{l}\text { numeracy } \\
\text { (sd) }\end{array}$ \\
\hline Controls* & 155 & 156 & 3275 & 64.33 & 15.18 & 55.73 & 15.91 \\
\hline Treated & 152 & 152 & 3469 & 65.63 & 15.10 & 56.79 & 16.40 \\
\hline Overall & 155 & 308 & 6744 & 65.00 & 15.15 & 56.28 & 16.17 \\
\hline $\begin{array}{l}\text { national INVALSI } \\
\text { controlled sample }\end{array}$ & 1296 & 2074 & 41539 & 60.80 & 11.00 & 50.90 & 19.00 \\
\hline
\end{tabular}

There are less control than treated classes because in three schools there was no other class than the treated one while in one school there were two treated classes to whom we chose to match just one control class.

The same classes were re-tested three years later at the end of grade 8 to collect the information on students achievement needed to measure the causal effect of the program. The two tests are not anchored so that we cannot measure the value-added at the individual level. Apart from information on students achievement and on their socio-economic background, we were not provided any information on schools (in particular on pre-existing ICT endowment) and on teachers (teaching experience and qualifications).

The evaluation of the program included an implementation analysis made up of three main components:

1) Teachers in the treated classes have been required to compile three questionnaires - one per school year - on the teaching practices they introduced in their class following the introduction of new technologies and on their perceptions of the impact these new practices had on students (response rate: $80.1 \%, 64.1 \%$ and $69.9 \%$, respectively). In addition, all teachers included in the study - either in a treated or in a control class - have been required to compile a questionnaire by the end of the third year on their level of qualification and familiarity with ICT (475 respondents out of a potential population of 1500 teachers - school coverage reaches $77.6 \%$ ).

2) School principals were surveyed twice, on technology adoption and on teachers turnover in the classes included in the study (response rate: $48.1 \%$ in the first survey via e-mail: $99 \%$ in the second survey, based on phone calls from the Ministry).

3) One external experienced observer visited 40 schools in the period Dec. 2011-Jan. 2012 to provide a report on the context in which the program has been implemented, on the targets the schools identified at the outset and on the practices they were implementing. We also draw from his report to provide an interpretation of the main findings of the evaluation exercise (see Section 4.3)

\footnotetext{
${ }^{6}$ We tested the competences of $6^{\text {th }}$ graders using an ad hoc slight variation of the test developed to assess literacy and numeracy at the exit of primary school $\left(5^{\text {th }}\right.$ grade $)$. The values in the final line of table 1 report the nation-wide distribution of such a test. The test score corresponds to the number of correct answers out of 100 questions. Thus the minimum and maximum values are 0 and 100, with a standard deviation between 15 and 16, depending on the area of testing.
} 
Table 2: School distribution by participation in the surveys (teachers and school principals)

\begin{tabular}{lcc}
\hline & $N$ & $\%$ \\
\hline no reaction & 7 & 4.5 \\
participated to 1 survey & 13 & 8.3 \\
participated to 2 surveys & 16 & 10.3 \\
participated to 3 surveys & 33 & 21.1 \\
participated to 4 surveys & 41 & 26.3 \\
participated to all surveys & 46 & 29.5 \\
\hline Total & 156 & 100 \\
\hline
\end{tabular}

The information we recovered from these sources on teacher perceptions and practices are rich but irregular and dispersed so that they do not lend themselves to a formal impact evaluation (see table 2 ). This is why we restrict our analysis to the impact on learning achievements by comparing treated to control classes. Still, from the scattered information resulting from the implementation analysis we get three main messages:

i) as a matter of fact, the treatment had variable intensity due to delays in implementation. By March 2010 (first year) only $50 \%$ of the schools already started using newly acquired technologies. The percentage rose to approximately $70 \%$ by the end of the first school year (June 2010) and to $90 \%$ by November 2010 (beginning of the second year). See figure 1.

Figure 1: Cumulative fraction of schools introducing newly acquired ICT by month (75 respondent schools)

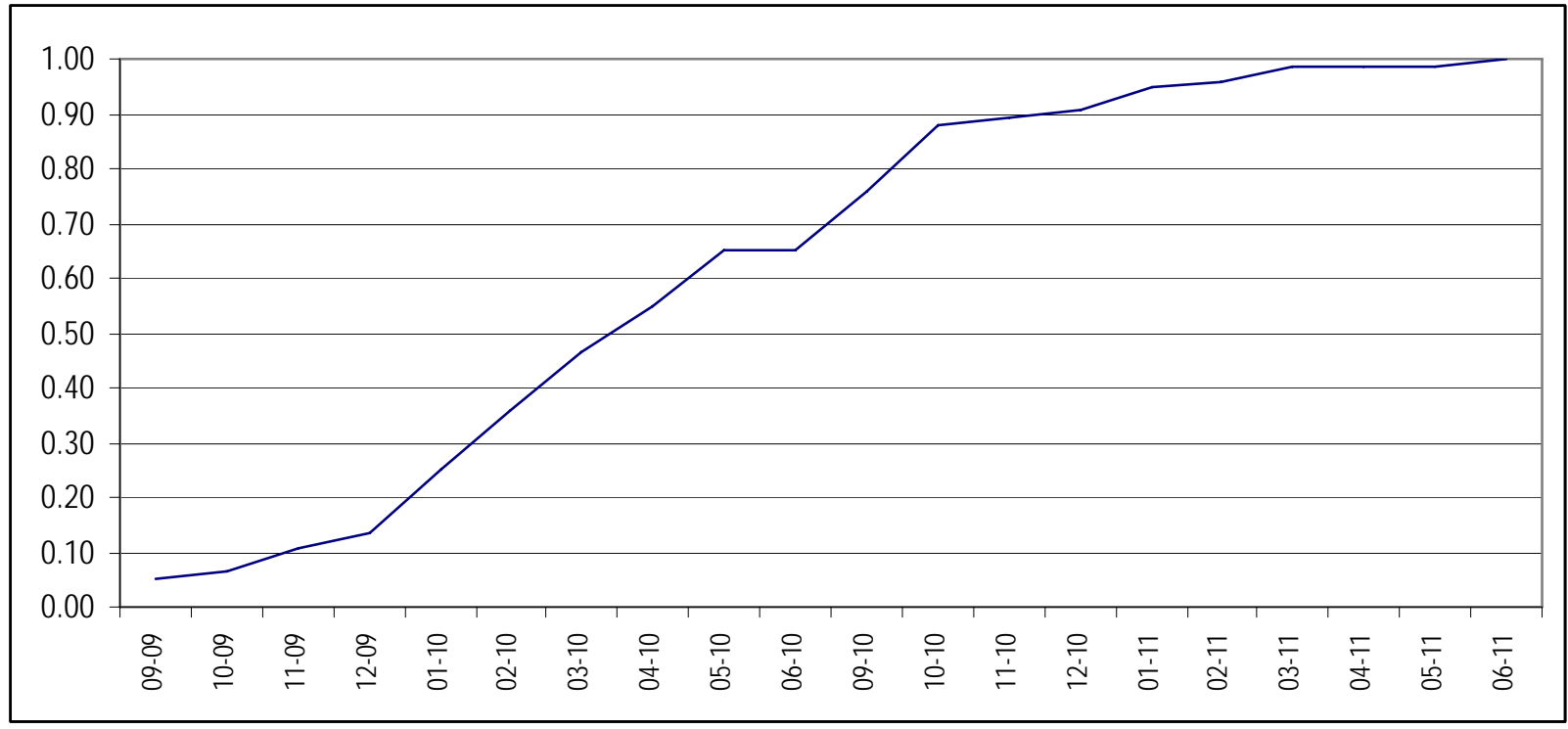

ii) The vast majority of schools bought notebooks/tablet and interactive whiteboards, but we ignore the exact amount because the schools were not requested to produce any cash statement at the end of the project. Based on interviews we obtain the picture shown in table 3 . Notice the large fraction of classes purchasing equipment related to documenting (camcorder and cameras) and image manipulation (scanner and projectors). Sounds and music were also conceived, though at a lower rate. Some schools located in socially deprived areas also bought specific safe cases for portable computer protection (and recharge). 
Table 3: Fraction of treated schools acquiring the following technologies

\begin{tabular}{lcc}
\hline & according to school principals & according to class coordinators \\
\hline tablet/pc/notebook & 100.0 & 87.2 \\
whiteboard interactive & 89.7 & 73.8 \\
camcorder & 37.3 & 41.8 \\
photographic equipment & 28.0 & 35.5 \\
multifunction printer/scanner & 28.0 & $\mathrm{nc}$ \\
class furniture & 20.0 & $\mathrm{nc}$ \\
recorder and/or player & 17.3 & $\mathrm{nc}$ \\
Projector & 10.7 & 39.0 \\
broadband internet connection & 10.7 & 34.0 \\
\hline number of respondent schools & 75 & 141 \\
\hline
\end{tabular}

iii) Despite an explicit Ministry directive prohibiting the sharing of newly bought technical equipment with other classes in the school, at least in some schools there is evidence that ICT have been shared with other classes, including control classes. It should also be noted that to a degree this is unavoidable since only the home language teacher is dedicated to a specific class, while all other teachers teach in more than one class. In personal interviews some teachers defended their violation of the Ministerial rules, on behalf of students: "If I find a learning object that is effective in teaching, why should I refrain from using it within all other classes where I teach?". Sharing of technology may be reduced when schools were located in more than one building. ${ }^{7}$ However the more problematic contamination is between treatment and control classes, which according to the interviews to school principals is limited to one out of ten cases (but is larger according to teachers' opinions - see table 4, noticing that the questions posed to teachers and school principals have a different coverage: teacher were asked about sharing new ICT among school classes, while school principals were restricted to answer about treated and control classes).

Table 4: Percentage of schools in which the Cl@ssi 2.0 ICT have been shared with other classes in the school

\begin{tabular}{lc}
\hline $\begin{array}{l}\text { The newly acquired ICT technologies under the project CO@ssi2.0 have been shared by other } \\
\text { classes in the school }\end{array}$ & $\begin{array}{c}\text { percentage of } \\
\text { positive answers }\end{array}$ \\
\hline respondent: school principals & 33.3 \\
respondent: teachers (1st questionnaire) & 20.8 \\
respondent: teachers (2nd questionnaire) & 63.0 \\
Combined information & 58.9 \\
The newly acquired ICT technologies under the project C@ossi2.0 has been shared by the control & \\
class in the school & \\
school principals & 11.3 \\
\hline
\end{tabular}

As an implication both of the contamination problem and of the variable intensity of the treatment documented so far the effect of the program on students achievement detected by our evaluation design should be regarded as a lower bound estimate on the true impact. If contamination had not taken effect with control classes, the score differential would have been wider. Similarly, if all schools had bought the intended equipment from the very beginning of the school year, the treatment would have extended over a longer period, and could have been potentially more effective.

\footnotetext{
${ }^{7}$ Treated and control classes were identified by a school code and a building code. We have therefore created a dummy variable indicating when treatment and control classes were located in the same building, making contamination possible. Nevertheless we never find statistical significance of this variable.
} 


\section{The analysis of the data from the quasi-experiment}

\subsection{On the comparability of the treatment and control groups}

To begin with we check the degree of comparability of classes and students assigned to participate into the program to classes and students in the same schools included in the comparison group. We assess the degree of comparability as of November 2009, i.e. at the beginning of the program. Table 5 presents the results of regressing the binary treatment status on observable characteristics of the student and of her family. Column 1 contains a linear probability regression including only information on the students collected from the school register. ${ }^{8}$ Columns 2 and 3 add sets of observable characteristics of the student family reported by the student herself at the benchmark survey. ${ }^{9}$ Overall, there seems to be no systematic difference between the two groups of classes with respect to the observable characteristics of the students (except for a marginally significant difference with respect to age).

Table 5: Probability of being assigned to a treated class as a function of observable characteristics of students

\begin{tabular}{|c|c|c|c|}
\hline & 1 & 2 & 3 \\
\hline & $\begin{array}{c}\text { linear } \\
\text { probability }\end{array}$ & $\begin{array}{c}\text { linear } \\
\text { probability }\end{array}$ & $\begin{array}{c}\text { linear } \\
\text { probability }\end{array}$ \\
\hline \multirow[t]{2}{*}{ Female } & 0.006 & 0.003 & 0.003 \\
\hline & [0.010] & [0.013] & [0.013] \\
\hline \multirow[t]{2}{*}{ birth year } & -0.001 & -0.001 & -0.002 \\
\hline & [0.002] & [0.002] & [0.002] \\
\hline \multirow[t]{2}{*}{ foreign born } & -0.014 & -0.016 & -0.011 \\
\hline & {$[0.019]$} & {$[0.030]$} & [0.031] \\
\hline \multirow[t]{2}{*}{ disabled } & 0.01 & 0.052 & 0.032 \\
\hline & {$[0.027]$} & [0.036] & [0.042] \\
\hline \multirow[t]{2}{*}{ at least one college graduate parent } & & -0.02 & -0.019 \\
\hline & & [0.017] & {$[0.017]$} \\
\hline \multirow[t]{2}{*}{ speaking Italian at home } & & -0.007 & -0.003 \\
\hline & & [0.022] & [0.022] \\
\hline \multirow[t]{2}{*}{ book shelves at home } & & 0.009 & 0.01 \\
\hline & & {$[0.007]$} & {$[0.007]$} \\
\hline \multirow[t]{2}{*}{ number of siblings } & & & 0.003 \\
\hline & & & {$[0.008]$} \\
\hline \multirow[t]{2}{*}{ cohabiting with two parents } & & & 0.008 \\
\hline & & & [0.021] \\
\hline \multirow[t]{2}{*}{ working mother } & & & -0.009 \\
\hline & & & [0.018] \\
\hline \multirow[t]{2}{*}{ working father } & & & -0.026 \\
\hline & & & [0.035] \\
\hline Observations & 6731 & 5533 & 5263 \\
\hline $\mathrm{R}^{2}$ & 0.00 & 0.00 & 0.00 \\
\hline
\end{tabular}

robust standard errors clustered at school level - constant and regional controls included

* significant at $10 \%$; * significant at $5 \%$; *** significant at $1 \%$

\footnotetext{
${ }^{8}$ Results are almost identical if we were to consider a probit model. Available from the authors. Also including school fixed effects does not change the picture since by design there is one treated and one control class in (nearly) each school hence the OLS is equivalent to a fixed-effect estimator.

${ }^{9}$ The sample size drops because of missing data. Starting from 6744 students under analysis, 13 do not allow the retrieval of their birth year from misspelled social security number (column 1), while other 1037 observations are lost due to non reporting of parental education. Descriptive statistics (including non missing observations) are reported in table A.1 in the Appendix.
} 
Table 6 presents the results of comparing treated classes to control ones with respect to the student degree of literacy (columns 1-3) and numeracy (columns 4-6) as of November 2009 at the benchmark survey. ${ }^{10}$ Clear - even if small - differences emerge between the two groups. Classes included in the treatment group perform marginally better (8-9\% of a standard deviation) than the other classes, both in literacy and numeracy domains, and the differences do not vanish adding in additional control variables and the school fixed-effects. We shall account for these differences in the estimation of the impact of the program by including the test scores at the benchmark survey as a control variable.

The other evidence from Table 6 are in line with standard results in this literature: worse performers are to be found among foreign born students, students speaking dialect or foreign language at home, students with less educated parents and/or fewer educational resources at home, students with a single parent and/or many siblings, students with a working mother.

Table 6: Regression of the literacy and numeracy score at the benchmark survey $\left(6^{\text {th }}\right.$ grade beginning of school year 2009-10) on the treatment status

\begin{tabular}{|c|c|c|c|c|c|c|}
\hline & 1 & 2 & 3 & 4 & 5 & 6 \\
\hline & $\begin{array}{l}\text { Literacy } \\
\text { score }\end{array}$ & $\begin{array}{l}\text { Literacy } \\
\text { score }\end{array}$ & $\begin{array}{l}\text { Literacy } \\
\text { score }\end{array}$ & $\begin{array}{c}\text { numeracy } \\
\text { score }\end{array}$ & $\begin{array}{c}\text { numeracy } \\
\text { score }\end{array}$ & $\begin{array}{c}\text { numeracy } \\
\text { score }\end{array}$ \\
\hline \multirow[t]{2}{*}{ treated class } & 1.328 & 1.459 & 1.47 & 1.115 & 1.31 & 1.344 \\
\hline & {$[0.484]^{\star \star \star}$} & {$[0.478]^{\star \star \star}$} & {$[0.489]^{\star \star \star}$} & {$[0.619]^{*}$} & {$[0.639]^{\star \star}$} & {$[0.635]^{\star \star}$} \\
\hline \multirow[t]{2}{*}{ Female } & 1.363 & 0.869 & 0.795 & -1.454 & -2.027 & -1.995 \\
\hline & {$[0.371]^{\star \star \star}$} & {$[0.370]^{\star \star}$} & {$[0.383]^{\star \star}$} & {$[0.445]^{\star \star \star}$} & {$[0.437]^{\star \star \star}$} & {$[0.439]^{\star \star \star}$} \\
\hline \multirow[t]{2}{*}{ birth year } & 0.151 & 0.055 & 0.049 & 0.202 & 0.1 & 0.105 \\
\hline & {$[0.098]$} & {$[0.060]$} & {$[0.060]$} & {$[0.095]^{\star \star}$} & {$[0.059]^{\star}$} & {$[0.058]^{*}$} \\
\hline \multirow[t]{2}{*}{ foreign born } & -14.884 & -8.831 & -9.089 & -9.535 & -4.978 & -5.166 \\
\hline & {$[0.968]^{\star \star \star}$} & {$[0.974]^{\star \star \star}$} & {$[0.943]^{\star \star \star}$} & {$[0.901]^{\star \star \star}$} & {$[0.958]^{\star \star \star}$} & {$[0.973]^{\star \star \star}$} \\
\hline \multirow[t]{2}{*}{ at least one college graduate parent } & & 1.787 & 1.074 & & 1.322 & 0.596 \\
\hline & & {$[0.474]^{\star \star \star}$} & {$[0.470]^{\star \star}$} & & {$[0.556]^{\star \star}$} & {$[0.556]$} \\
\hline \multirow[t]{2}{*}{ speaking Italian at home } & & 2.251 & 1.917 & & 2.018 & 1.841 \\
\hline & & {$[0.624]^{\star \star \star}$} & {$[0.591]^{\star \star \star}$} & & {$[0.532]^{\star \star \star}$} & {$[0.512]^{\star \star \star}$} \\
\hline \multirow[t]{2}{*}{ book shelves at home } & & 3.204 & 2.942 & & 3.077 & 2.834 \\
\hline & & {$[0.181]^{\star \star \star}$} & {$[0.185]^{\star \star \star}$} & & {$[0.193]^{\star \star \star}$} & {$[0.201]^{\star \star \star}$} \\
\hline \multirow[t]{2}{*}{ number of siblings } & & -1.417 & -1.235 & & -1.079 & -0.974 \\
\hline & & {$[0.225]^{\star \star \star}$} & {$[0.216]^{\star \star \star}$} & & {$[0.284]^{\star \star \star}$} & {$[0.272]^{\star \star \star}$} \\
\hline \multirow[t]{2}{*}{ cohabiting with two parents } & & 2.896 & 2.672 & & 3.301 & 2.986 \\
\hline & & {$[0.589]^{\star \star \star}$} & {$[0.594]^{\star \star \star}$} & & {$[0.594]^{\star \star \star}$} & {$[0.590]^{\star \star \star}$} \\
\hline \multirow[t]{2}{*}{ working mother } & & 0.98 & 0.796 & & 1.161 & 0.843 \\
\hline & & {$[0.447]^{\star \star}$} & {$[0.434]^{*}$} & & {$[0.478]^{\star \star}$} & {$[0.472]^{*}$} \\
\hline \multirow[t]{2}{*}{ working father } & & 1.616 & 1.497 & & 0.568 & 0.359 \\
\hline & & [1.069] & [1.092] & & [0.992] & {$[0.981]$} \\
\hline School fixed-effect & no & no & yes & no & no & Yes \\
\hline Observations & 5970 & 5106 & 5106 & 5999 & 5134 & 5134 \\
\hline$\overline{\mathrm{R}^{2}}$ & 0.10 & 0.19 & 0.25 & 0.10 & 0.17 & 0.24 \\
\hline
\end{tabular}

robust standard errors clustered at school level - constant and regional controls included

$*$ significant at $10 \% ; * *$ significant at $5 \% ; * * *$ significant at $1 \%$

A key step to implement the estimation of the impact of the program is the linkage of the student records at the benchmark survey to the corresponding records resulting from the achievement test

\footnotetext{
${ }^{10}$ We controlled for non random participation to the initial survey. Results reported in table A.2 in the Appendix suggest that older boys who are foreign born are more likely to have avoided sitting the test. It may also be the mere reflection of non random truancy rates.
} 
by the end of the $8^{\text {th }}$ grade. Due to a change in the privacy protection policy ${ }^{11}$ the linkage did not succeed for approximately one third of the students included in the original sample. This is due to problems both at the class and at the student level. Closure of some schools (or merger with other schools) are responsible for the loss of track for approximately $10 \%$ of the classes included in the original sample. Migrations of students and failures of some of them added some additional loss of track. Overall, we are left with 134 schools out of the original 156 in which both the treated and the control classes are available in the final sample, i.e. with information both at the $6^{\text {th }}$ and at the $8^{\text {th }}$ grade. $^{12}$

Table 7: Attrition of classes and students between the entry test at grade 6 (school year 2009-10) and the final test at grade 8 (school year 2011-12)

\begin{tabular}{|l|c|c|c|c|c|c|}
\hline & $\begin{array}{c}\text { lack of match } \\
\text { at class level }\end{array}$ & $\begin{array}{c}\text { total } \\
\text { classes }\end{array}$ & Attrition & $\begin{array}{c}\text { lack of match } \\
\text { at student } \\
\text { level }\end{array}$ & $\begin{array}{c}\text { total } \\
\text { student }\end{array}$ & attrition \\
\hline Treated & 17 & 156 & $10.90 \%$ & 1141 & 3469 & $32.9 \%$ \\
\hline Controls & 16 & 152 & $10.46 \%$ & 1116 & 3275 & $34.1 \%$ \\
\hline Overall project cl@ssi2.0 & 33 & 308 & $10.68 \%$ & 2257 & 6744 & $33.5 \%$ \\
\hline
\end{tabular}

Table 8 provides some evidence on the attrition process. Results from regressing the binary variable 'still in the sample by grade $8^{\text {th }}$ on students' characteristics collected at grade $6^{\text {th }}$ show that controlling for schools fixed-effect, gender, age, students cohabiting with both parents students with higher score at the benchmark survey are less likely to attrite away. This last effect is almost by construction, since good students are less likely to be failed. Note however that the treatment status does not produce any differential effect of initial competences on the probability of continuing in the sample (see the interaction added in column 6).

\footnotetext{
${ }^{11}$ Until 2010 students were identified by their social security number, which in Italy provides information about gender, age and place of birth. The privacy protection policy imposed by the national Authority led to the abandonment of this identifier and its replacement by a student identifier which in principle should correspond univocally to the original code but fully preserving anonymity. In the transition to the new system, some schools were unable to implement the new procedure, which explain the loss of one third of our students. We investigated whether this delay in implementation was systematically associated to any observable characteristics of the school without being able to find any consistent pattern. Thus we deem that the attrition is not systematically connected to our object of investigation (see table 8 below).

${ }^{12}$ Out of the original 156 treated classes, 3 of them lack appropriate control classes and 2 treated classes were in the same school with only one control class since the beginning of the program (see footnote to Tab. 1). 2 schools were closed/merged during the sample period and 16 did not comply with the new identification procedures for the student. Thus we are left with 134 appropriate treated-control matches at class level.
} 
Table 8: Probability of persisting in the sample after 3 years (from school year 2009-10 to school year 2011-12)

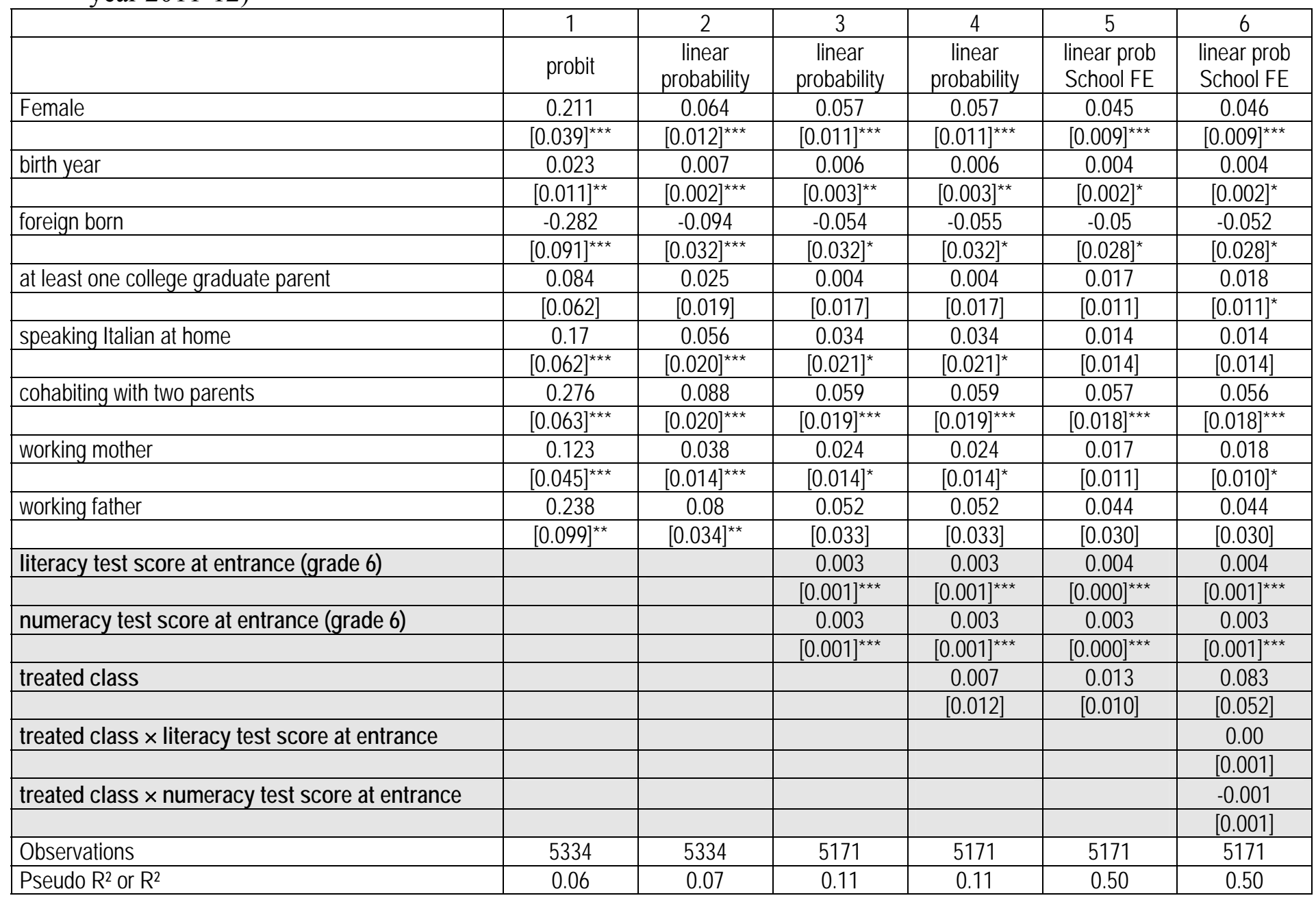

robust standard errors clustered at school level - constant and regional controls included

* significant at $10 \%$; ** significant at $5 \%$; ${ }^{* \star *}$ significant at $1 \%$

Eventually, our working sample for the estimation of the impact on students' achievement of Cl@asse 2.0 is made up of 4487 students belonging to either the treatment or the control class in 134 schools. Tab. 9 presents summary statistics by treatment status. The test score is the number of correct answers over 100 questions.

Note that starting with the school year 2011-2012 test scores provided by INVALSI in their public use files are rescaled by the factor [1-probability of cheating] where probability of cheating is determined at the class - not at the individual! - level according to an INVALSI protocol. ${ }^{13}$ In Tab. 9 we refer to the original data, not to those corrected for cheating.

\footnotetext{
${ }^{13}$ Invalsi estimates the probability of cheating using a statistical model suspecting for surprisingly large average scores, low within-class variability, and suspect patterns of missing values. See Quintano et al. 2009. There is evidence of reduction of cheating when external monitors are introduced (Bertoni et al. 2013).
} 
Table 9: Descriptive statistics of the working sample

\begin{tabular}{|c|c|c|c|}
\hline & $\begin{array}{c}\text { Students } \\
\text { in treated } \\
\text { classes }\end{array}$ & \begin{tabular}{|c|} 
Students \\
in control \\
classes
\end{tabular} & $\begin{array}{l}\text { overall } \\
\text { sample }\end{array}$ \\
\hline Observations & 2328 & 2159 & 4487 \\
\hline fraction of girls & $49 \%$ & $50 \%$ & $50 \%$ \\
\hline birth year: 1994 & $0.04 \%$ & $0.00 \%$ & $0.04 \%$ \\
\hline birth year: 1995 & $0.04 \%$ & $0.09 \%$ & $0.07 \%$ \\
\hline birth year: 1996 & $0.47 \%$ & $0.74 \%$ & $0.60 \%$ \\
\hline birth year: 1997 & $3.78 \%$ & $3.57 \%$ & $3.68 \%$ \\
\hline birth year: 1998 (regular students) & $87.06 \%$ & $87.40 \%$ & $87.23 \%$ \\
\hline birth year: 1999 & $8.47 \%$ & $8.01 \%$ & $8.25 \%$ \\
\hline foreign born & $6 \%$ & $6 \%$ & $6 \%$ \\
\hline speaking Italian at home & $79 \%$ & $79 \%$ & $79 \%$ \\
\hline at least one parent with college & $30 \%$ & $32 \%$ & $31 \%$ \\
\hline cohabiting with two parents & $88 \%$ & $87 \%$ & $87 \%$ \\
\hline \multirow{2}{*}{$\begin{array}{l}\text { literacy score } 6^{\text {th }} \text { grade } \\
\text { (mean - standard deviation in brackets) }\end{array}$} & 67.38 & 66.55 & 66.98 \\
\hline & $(14.39)$ & $(14.35)$ & $(14.37)$ \\
\hline \multirow{2}{*}{$\begin{array}{l}\text { numeracy score } 6^{\text {th }} \text { grade } \\
\text { (mean - standard deviation in brackets) }\end{array}$} & 58.54 & 57.95 & 58.26 \\
\hline & $(16.06)$ & $(15.49)$ & $(15.79)$ \\
\hline \multirow{2}{*}{$\begin{array}{l}\text { literacy score } 8^{\text {th }} \text { grade, original values } \\
\text { (mean - standard deviation in brackets) }\end{array}$} & 75.65 & 75.18 & 75.43 \\
\hline & $(12.48)$ & $(13.74)$ & $(13.10)$ \\
\hline \multirow{2}{*}{$\begin{array}{l}\text { numeracy score } 8^{\text {th }} \text { grade, original values } \\
\text { (mean - standard deviation in brackets) }\end{array}$} & 56.80 & 56.49 & 56.65 \\
\hline & $(17.39)$ & $(17.44)$ & $(17.41)$ \\
\hline
\end{tabular}

\subsection{The impact of Cl@ssi 2.0 on student achievement}

Figures 2 and 3 present the distribution of the literacy and numeracy score, respectively, for students in the control and treatment classes. They also illustrate the difference between the original scores and the scores corrected by INVALSI to account for cheating.

Tables 10 and 11 present estimates for the average causal effect of the program from alternative specifications of the regression equation. The main difference between the two sets of results depends on the use we make of the information on cheating. In Table 10 we make use of the observed individual test scores and control for the estimated probability of cheating at the class level while in Table 11 we make use of the individual test scores as corrected by INVALSI to account for cheating. The correction - instead of the control - for cheating turns out to matter while the choice of the other control variables included in the regression (as well as controlling or not for school fixed effects) do not affect the main conclusion one can draw from the exercise. While using the original test score controlling for cheating the average impact is zero both for literacy and for numeracy (there is only a modest, marginally significant positive effect on numeracy for children of college graduate parents), when using the test score corrected for cheating a statistically significant average effect emerges on literacy in the range 2.0 to 3.5 points (i.e. correct answers) for children of uneducated parents (the coefficient on the interaction between the treatment status and the dummy for college graduate parents nearly offsets the main coefficient). Conversely, no effect can be found for numeracy. These results are nearly unaffected by the inclusion in the regression of additional control variables and of school fixed effects. As for the coefficient on the test score at grade 6 it is around 0.5. In the literature the coefficient for the test score lagged one year is typically found between 0.7 and 0.8 . Since in our case the test score is lagged twice the reference value falls in the range 0.49 to 0.64 in line with the value we find.

As a check on these results we replicated the analysis on class averages. The basic results of these additional regressions are in line with those here above (see tables A.3 and A.4 in the appendix). 
While there is almost no effect when original test scores are considered, we find some positive effect for treatment in literacy for corrected test scores, even if this effect is attenuated in classes where the share of children from college educated parents is higher (the effect is even reversed when the share of college educated parents exceeds $41 \%$, which corresponds to the $7^{\text {th }}$ decile in the class distribution, the median being $28 \%$ ). This is indication of potential heterogeneity of the effect of the treatment that we are going to address in the next steps.

Table 12 presents results for a regression in which the treatment status is interacted with the ranking of the students in the distribution of the score at the benchmark survey (beginning of grade $6^{\text {th }}$ ). As for the difference between using original vs corrected scores the overall evidence is in line with the previous findings. The news here are that the average positive impact of the program on literacy score detected by the regressions in Table 11 is driven by its causal effect on the bottom tail of the distribution ( $1^{\text {st }}$ decile) while the other part of the distribution are nearly unaffected. Results in Table 12 confirm that this causal effect is confined to children of uneducated parents. This is the only result consistent across all the specifications of the equation we considered. Apart from a few other significant estimates displaying no intelligible pattern, there is no other relevant evidence from this regression. The first six columns control for the extent of cheating, which is obviously correlated with the original test scores.

As a further check on the heterogeneity of the causal effect over the distribution of the outcome we run a set of quantile regressions but here we do not find results consistent across the two specifications we considered (controlling vs correcting for cheating - see tables A.5 and A.6 in the appendix). 
Figure 2: Distribution of the literacy score by treatment status - end of grade $8^{\text {th }}$ (sc.year 2011-12)

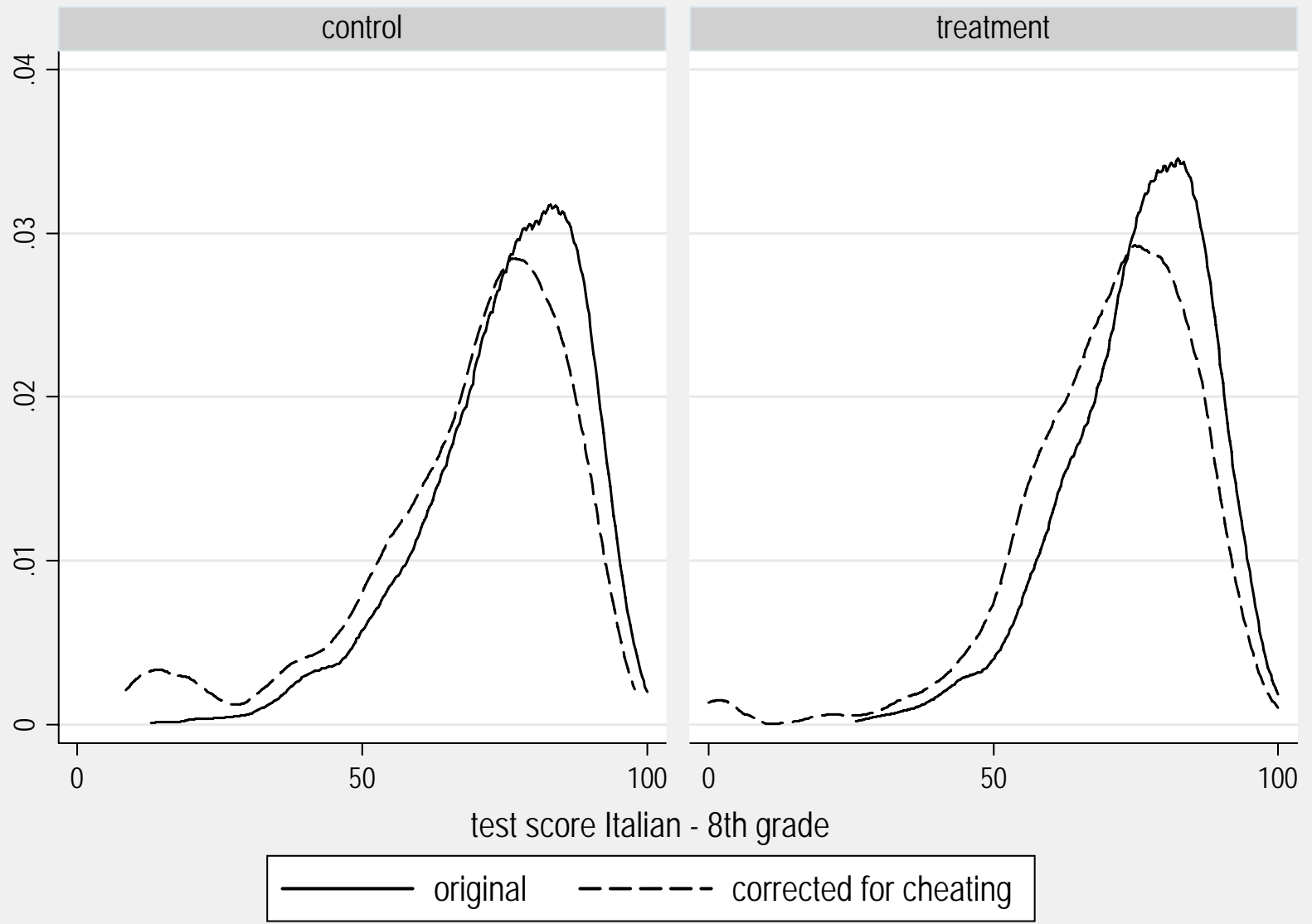

Figure 3: Distribution of the numeracy score by treatment status - end of grade $8^{\text {th }}$ (sc.year 2011-12)

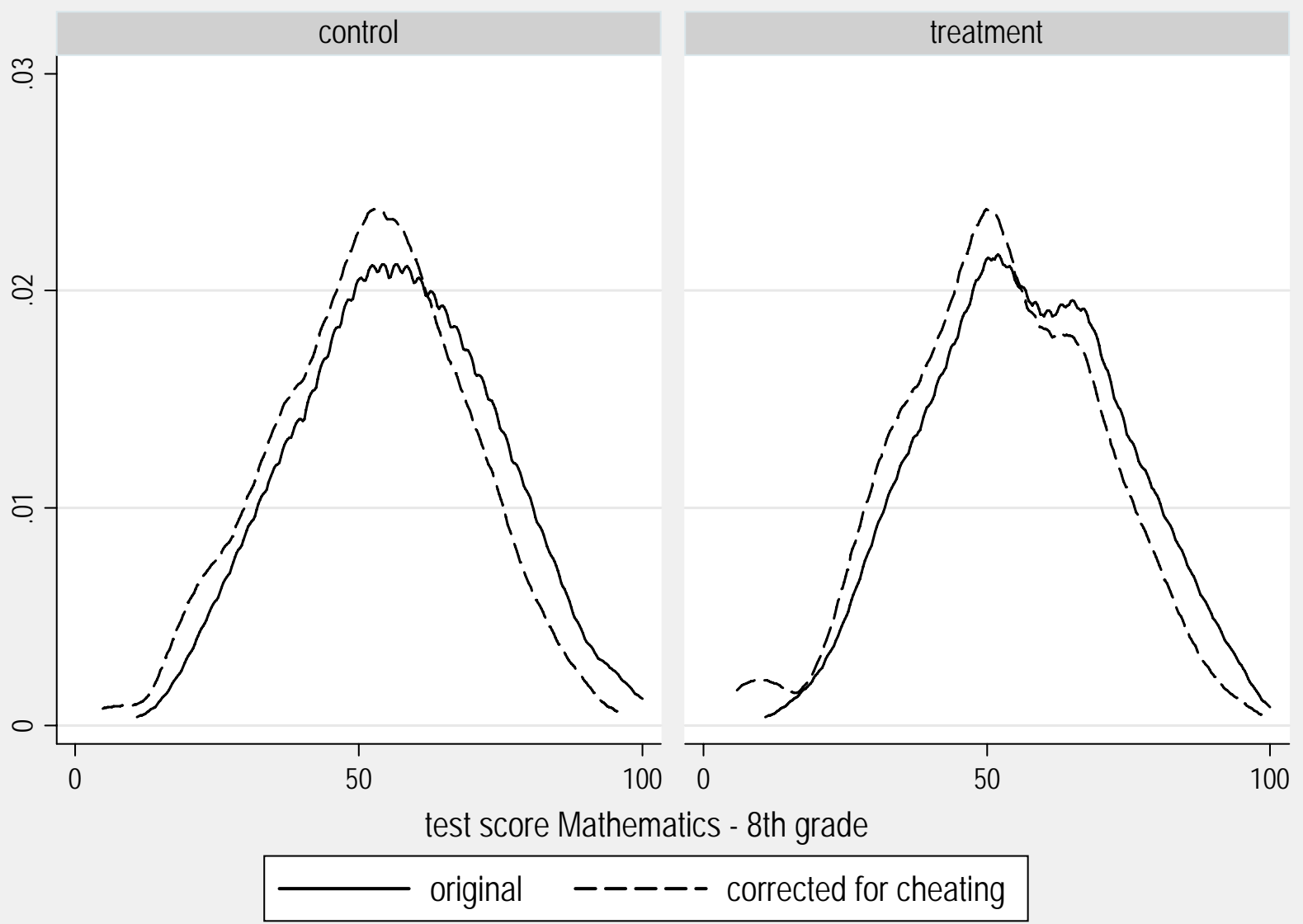


Table 10: The effect of $\mathrm{Cl} @$ sse 2.0 on test scores by the end of $8^{\text {th }}$ grade (original test scores) individual data

\begin{tabular}{|c|c|c|c|c|c|c|c|c|}
\hline & \multicolumn{4}{|c|}{ Literacy } & \multicolumn{4}{|c|}{ Numeracy } \\
\hline & 1 & 2 & 3 & 4 & 5 & 6 & 7 & 8 \\
\hline test score at entrance (6 $6^{\text {th }}$ grade) & 0.515 & 0.526 & 0.526 & 0.5 & 0.526 & 0.532 & 0.532 & 0.516 \\
\hline treated class & [0.738] & [0.528] & [0.578] & [0.560] & [1.336] & [0.893] & [0.972] & [0.994] \\
\hline \multirow[t]{2}{*}{ probability of cheating (estimated at class level) } & 16.581 & 11.452 & 11.524 & 11.745 & 38.52 & 34.244 & 34.193 & 33.852 \\
\hline & {$[1.953]^{\star \star \star}$} & {$[1.155]^{\star \star \star}$} & {$[1.165]^{\star \star \star}$} & {$[1.163]^{\star \star \star}$} & {$[3.812]^{\star \star \star}$} & {$[5.177]^{\star \star \star}$} & {$[5.137]^{\star \star \star}$} & {$[5.374]^{\star \star \star}$} \\
\hline \multirow[t]{2}{*}{ Female } & 0.776 & 0.639 & 0.638 & 0.506 & -0.566 & -0.488 & -0.486 & -0.736 \\
\hline & {$[0.348]^{\star \star}$} & {$[0.332]^{*}$} & {$[0.332]^{*}$} & [0.345] & [0.453] & [0.416] & [0.415] & {$[0.432]^{\star}$} \\
\hline \multirow[t]{2}{*}{ at least one college graduate parent } & 1.539 & 1.277 & 1.522 & 0.77 & 2.305 & 2.224 & 1.396 & 0.746 \\
\hline & {$[0.343]^{\star \star \star}$} & {$[0.366]^{\star \star \star}$} & {$[0.496]^{\star \star \star}$} & [0.531] & {$[0.528]^{\star \star \star}$} & {$[0.495]^{\star \star \star}$} & {$[0.670]^{\star \star}$} & [0.696] \\
\hline \multirow[t]{2}{*}{ at least one college graduate parent $\times$ treatment } & & & -0.484 & -0.524 & & & 1.629 & 1.624 \\
\hline & & & [0.659] & {$[0.677]$} & & & {$[0.915]^{*}$} & {$[0.952]^{*}$} \\
\hline \multirow{2}{*}{$\begin{array}{l}\text { fraction of permanent teachers (still in the school } \\
\text { after } 3 \text { years) }\end{array}$} & 1.854 & 2.312 & 2.265 & 1.976 & 4.208 & 1.502 & 1.63 & 1.458 \\
\hline & [1.782] & [2.118] & [2.120] & [2.051] & [3.184] & [3.766] & [3.778] & [3.727] \\
\hline \multirow[t]{2}{*}{ teacher in charge teaches language } & 1.674 & -0.091 & -0.094 & -0.062 & -0.079 & -2.812 & -2.804 & -2.525 \\
\hline & {$[0.987]^{\star}$} & {$[0.856]$} & {$[0.854]$} & {$[0.806]$} & [1.615] & [1.734] & [1.734] & [1.747] \\
\hline \multirow[t]{2}{*}{ teacher in charge teaches mathematics } & -0.067 & -1.403 & -1.408 & -1.318 & 0.911 & 0.859 & 0.874 & 1.106 \\
\hline & {$[0.859]$} & {$[0.854]$} & {$[0.853]^{*}$} & [0.812] & [1.834] & [1.412] & [1.414] & [1.432] \\
\hline speaking Italian at home & & & & 0.677 & & & & 1.607 \\
\hline \multirow[t]{2}{*}{ working mother } & & & & 0.755 & & & & 1.164 \\
\hline & & & & {$[0.385]^{\star}$} & & & & {$[0.512]^{\star \star}$} \\
\hline \multirow[t]{2}{*}{ working father } & & & & -0.107 & & & & -0.753 \\
\hline & & & & [0.806] & & & & [1.091] \\
\hline Observations & 4171 & 4171 & 4171 & 3917 & 4174 & 4174 & 4174 & 3920 \\
\hline $\mathrm{R}^{2}$ & 0.42 & 0.50 & 0.50 & 0.50 & 0.39 & 0.51 & 0.51 & 0.51 \\
\hline
\end{tabular}

robust standard errors clustered at school level - constant and regional controls included

Outlier students are defined as those with a score smaller than 10

* significant at $10 \%$; ${ }^{*}$ significant at $5 \%$; ** significant at $1 \%$ 
Table 11: The effect of $\mathrm{Cl} @$ ssi2.0 on test scores by the end of $8^{\text {th }}$ grade (test scores corrected for cheating) - individual data

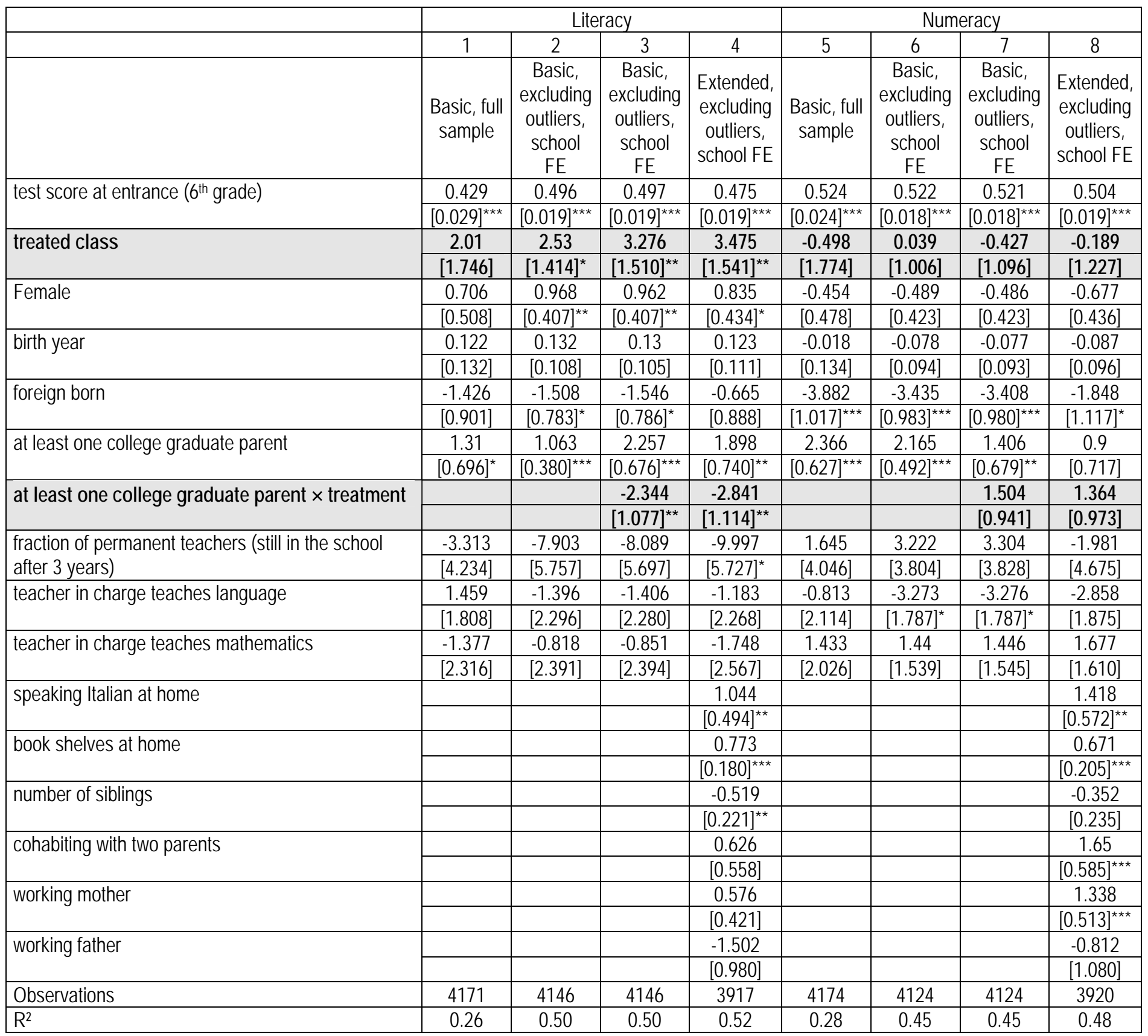

robust standard errors clustered at school level - constant and regional controls included

Outlier students are defined as those with a score smaller than 10

${ }^{*}$ significant at 10\%; ** significant at $5 \%$; ${ }^{* \star}$ significant at $1 \%$ 
Table 12: The effect of $\mathrm{Cl} @$ ssi2.0 on test scores at $8^{\text {th }}$ grade (original and corrected test scores) conditional on initial ranking of the student - individual data

\begin{tabular}{|c|c|c|c|c|c|c|c|c|c|c|c|c|}
\hline & 1 & 2 & 3 & 4 & 5 & 6 & 7 & 8 & 9 & 10 & 11 & 12 \\
\hline & \multicolumn{6}{|c|}{ original test scores } & \multicolumn{6}{|c|}{ corrected test scores } \\
\hline & Literacy & $\begin{array}{l}\text { Literacy, } \\
\text { school FE }\end{array}$ & $\begin{array}{c}\text { Literacy, } \\
\text { school FE }\end{array}$ & Numeracy & $\begin{array}{l}\text { Numeracy, } \\
\text { school FE }\end{array}$ & $\begin{array}{l}\text { Numeracy, } \\
\text { school FE } \\
\end{array}$ & Literacy & $\begin{array}{l}\text { Literacy, } \\
\text { school FE }\end{array}$ & $\begin{array}{l}\text { Literacy, } \\
\text { school FE }\end{array}$ & Numeracy & $\begin{array}{l}\text { Numeracy, } \\
\text { school FE }\end{array}$ & $\begin{array}{l}\text { Numeracy, } \\
\text { school FE }\end{array}$ \\
\hline \multirow{2}{*}{$\begin{array}{l}\text { test score at entrance } \\
\text { (6th grade) }\end{array}$} & 0.528 & 0.543 & 0.516 & 0.547 & 0.552 & 0.542 & 0.461 & 0.529 & 0.5 & 0.531 & 0.533 & 0.524 \\
\hline & {$[0.022]^{\star \star \star}$} & {$[0.018]^{\star \star \star}$} & {$[0.017]^{\star \star \star}$} & {$[0.028]^{\star \star \star}$} & {$[0.024]^{\star \star \star}$} & {$[0.023]^{\star \star \star}$} & {$[0.035]^{\star \star \star}$} & {$[0.022]^{\star \star \star}$} & {$[0.022]^{\star \star \star}$} & {$[0.031]^{\star \star \star}$} & {$[0.026]^{\star \star \star}$} & {$[0.025]^{\star \star \star}$} \\
\hline \multirow{2}{*}{$\begin{array}{l}\text { treatment } \times 1^{\text {st }} \text { decile } \\
6^{\text {th }} \text { grade }\end{array}$} & 2.231 & 2.791 & 2.708 & 1.894 & 1.826 & 2.885 & 5.48 & 5.194 & 4.833 & 1.373 & 1.642 & 2.681 \\
\hline & [1.629] & {$[1.397]^{\star \star}$} & {$[1.362]^{\star *}$} & [1.905] & [1.430] & {$[1.459]^{* *}$} & {$[2.074]^{\star \star \star}$} & {$[1.806]^{\star \star *}$} & {$[1.774]^{\star \star \star}$} & [2.242] & [1.577] & {$[1.588]^{*}$} \\
\hline \multirow{2}{*}{$\begin{array}{l}\text { treatment } \times 2^{\text {nd }} \text { decile } \\
6^{\text {th }} \text { grade }\end{array}$} & -0.002 & 0.329 & 0.183 & 2.888 & 2.031 & 2.738 & 2.342 & 1.586 & 0.503 & 2.304 & 1.712 & 2.406 \\
\hline & [1.422] & [1.147] & [1.078] & [1.855] & [1.445] & {$[1.380]^{\star \star}$} & [1.790] & [1.400] & [1.213] & [2.145] & [1.547] & [1.468] \\
\hline \multirow{2}{*}{$\begin{array}{l}\text { treatment } \times 3^{\text {rd }} \text { decile } \\
6^{\text {th }} \text { grade }\end{array}$} & 0.032 & -0.047 & 0.073 & -0.159 & -0.454 & -0.07 & 0.821 & 1.498 & 1.323 & -0.862 & -0.767 & -0.326 \\
\hline & [1.024] & [0.842] & [0.811] & [1.490] & [1.325] & [1.296] & [1.608] & [1.208] & [1.211] & [1.739] & [1.355] & [1.328] \\
\hline \multirow{2}{*}{$\begin{array}{l}\text { treatment } \times 4^{\text {th }} \text { decile } \\
6^{\text {th }} \text { grade }\end{array}$} & 0.244 & 0.238 & 0.103 & -1.692 & -1.983 & -1.337 & 1.829 & 1.46 & 0.777 & -3.744 & -2.863 & -2.302 \\
\hline & [0.972] & [0.763] & {$[0.729]$} & [1.273] & {$[1.061]^{\star}$} & [1.061] & [1.441] & [1.152] & [1.163] & {$[1.704]^{\star \star}$} & {$[1.175]^{\star \star}$} & {$[1.160]^{\star \star}$} \\
\hline \multirow{2}{*}{$\begin{array}{l}\text { treatment } \times 5^{\text {th }} \text { decile } \\
6^{\text {th }} \text { grade }\end{array}$} & 0.18 & 0.099 & -0.011 & -1.398 & -1.212 & -0.651 & 1.909 & 1.651 & 1.473 & -1.873 & -1.296 & -0.731 \\
\hline & {$[0.936]$} & [0.788] & {$[0.797]$} & [1.244] & [0.943] & [0.928] & {$[1.474]$} & [1.273] & [1.345] & [1.475] & [1.109] & [1.087] \\
\hline \multirow{2}{*}{$\begin{array}{l}\text { treatment } \times 6^{\text {th }} \text { decile } \\
6^{\text {th }} \text { grade }\end{array}$} & -1.075 & -1.604 & -1.666 & -1.222 & -1.256 & -0.449 & -0.128 & -0.42 & -0.892 & -0.771 & -1.285 & -0.472 \\
\hline & [0.838] & {$[0.730]^{\star \star}$} & {$[0.735]^{\star \star}$} & [1.211] & [0.962] & {$[0.905]$} & [1.571] & [1.178] & [1.158] & [1.319] & [1.013] & [0.945] \\
\hline \multirow{2}{*}{$\begin{array}{l}\text { treatment } \times 7^{\text {th }} \text { decile } \\
6^{\text {th }} \text { grade }\end{array}$} & 0.574 & 0.519 & 0.498 & -1.847 & -2.603 & -2.094 & 1.493 & 2.176 & 1.969 & -1.645 & -2.731 & -2.155 \\
\hline & {$[0.643]$} & [0.566] & {$[0.555]$} & [1.219] & {$[0.934]^{\star \star \star}$} & {$[0.903]^{\star \star}$} & {$[1.507]$} & {$[1.185]^{*}$} & [1.249] & [1.442] & {$[1.003]^{\star \star \star}$} & {$[0.989]^{\star \star}$} \\
\hline \multirow{2}{*}{$\begin{array}{l}\text { treatment } \times 8^{\text {th }} \text { decile } \\
6^{\text {th }} \text { grade }\end{array}$} & 0.697 & 0.597 & 0.632 & -0.969 & -1.875 & -1.37 & 1.754 & 1.017 & 0.768 & -0.6 & -1.789 & -1.221 \\
\hline & [0.704] & [0.691] & [0.682] & [1.269] & {$[1.042]^{\star}$} & [1.040] & [1.531] & [0.989] & {$[1.043]$} & [1.363] & {$[1.068]^{\star}$} & {$[1.064]$} \\
\hline \multirow{2}{*}{$\begin{array}{l}\text { treatment } \times 9^{\text {th }} \text { decile } \\
6^{\text {th }} \text { grade } \\
\end{array}$} & -1.054 & -1.242 & -1.079 & -0.26 & -1.28 & -0.629 & 0.118 & 0.219 & -0.098 & 0.015 & -1.151 & -0.601 \\
\hline & {$[0.593]^{\star}$} & {$[0.561]^{\star \star}$} & {$[0.564]^{\star}$} & [1.239] & [1.094] & [1.064] & [1.614] & [1.032] & [1.078] & [1.349] & [1.121] & [1.097] \\
\hline \multirow{2}{*}{$\begin{array}{l}\text { probability of cheating } \\
\text { (estim. at class level) }\end{array}$} & 16.734 & 11.831 & 11.992 & 38.747 & 33.414 & 33.209 & & & & & & \\
\hline & {$[1.986]^{\star \star \star}$} & {$[1.149]^{\star \star \star}$} & {$[1.139]^{\star \star \star}$} & {$[3.697]^{\star \star \star}$} & {$[5.181]^{\star \star \star}$} & {$[5.482]^{\star \star \star}$} & & & & & & \\
\hline \multirow{2}{*}{ female } & 0.766 & 0.641 & 0.504 & -0.58 & -0.476 & -0.727 & 0.744 & 0.943 & 0.853 & -0.449 & -0.431 & -0.665 \\
\hline & {$[0.350]^{\star \star}$} & {$[0.331]^{*}$} & [0.343] & {$[0.454]$} & {$[0.413]$} & {$[0.432]^{*}$} & {$[0.509]$} & {$[0.407]^{\star \star}$} & {$[0.434]^{\star}$} & {$[0.482]$} & {$[0.413]$} & [0.433] \\
\hline \multirow{2}{*}{ birth year } & 0.148 & 0.139 & 0.129 & -0.049 & -0.076 & -0.092 & 0.131 & 0.148 & 0.147 & -0.026 & -0.069 & -0.085 \\
\hline & {$[0.099]$} & {$[0.103]$} & {$[0.105]$} & {$[0.117]$} & {$[0.090]$} & {$[0.093]$} & {$[0.143]$} & {$[0.108]$} & {$[0.119]$} & {$[0.133]$} & {$[0.091]$} & [0.092] \\
\hline \multirow{2}{*}{ foreign born } & -1.552 & -1.622 & -0.893 & -4.492 & -3.694 & -2.095 & -1.631 & -1.564 & -0.669 & -3.977 & -3.523 & -1.977 \\
\hline & {$[0.794]^{*}$} & {$[0.782]^{\star \star}$} & {$[0.869]$} & {$[1.029]^{\star \star \star}$} & {$[0.953]^{\star \star \star}$} & {$[1.069]^{\star}$} & {$[0.894]^{\star}$} & {$[0.781]^{\star \star}$} & {$[0.868]$} & {$[1.013]^{\star \star \star}$} & {$[0.972]^{\star \star \star}$} & {$[1.118]^{\star}$} \\
\hline \multirow{2}{*}{$\begin{array}{l}\text { at least one parent } \\
\text { with college }\end{array}$} & 1.498 & 1.41 & 0.484 & 2.296 & 1.244 & 1.55 & 1.206 & 1.838 & 0.385 & 2.341 & 1.27 & 1.553 \\
\hline & {$[0.340]^{\star \star \star}$} & {$[0.483]^{\star \star \star}$} & {$[0.392]$} & {$[0.533]^{\star \star \star}$} & {$[0.651]^{*}$} & {$[0.531]^{\star \star \star}$} & {$[0.683]^{\star}$} & {$[0.676]^{\star \star \star}$} & [0.415] & {$[0.639]^{\star \star \star}$} & {$[0.652]^{\star}$} & {$[0.550]^{\star \star \star}$} \\
\hline \multirow{2}{*}{$\begin{array}{l}\text { at least one parent } \\
\text { with collegextreatm }\end{array}$} & & -0.313 & & & 1.879 & & & -1.507 & & & 1.715 & \\
\hline & & {$[0.602]$} & & & {$[0.831]^{\star \star}$} & & & {$[1.017]$} & & & {$[0.850]^{\star \star}$} & \\
\hline Italian spoken at & & & 0.675 & & & 1.584 & & & 1.022 & & & 1.377 \\
\hline home & & & [0.420] & & & {$[0.565]^{\star \star \star}$} & & & {$[0.497]^{\star \star}$} & & & {$[0.584]^{\star \star}$} \\
\hline number of books at & & & 0.8 & & & 0.7 & & & 0.761 & & & 0.66 \\
\hline & & & {$[0.150]^{\star \star \star}$} & & & {$[0.208]^{\star \star \star}$} & & & {$[0.177]^{\star \star \star}$} & & & {$[0.206]^{\star \star \star}$} \\
\hline & & & -0.529 & & & -0.403 & & & -0.508 & & & -0.392 \\
\hline & & & {$[0.197]^{\star \star \star}$} & & & {$[0.240]^{\star}$} & & & {$[0.223]^{\star \star}$} & & & {$[0.236]^{\star}$} \\
\hline living with two & & & 0.959 & & & 1.62 & & & 0.639 & & & 1.627 \\
\hline & & & {$[0.505]^{\star}$} & & & {$[0.580]^{\star \star \star}$} & & & {$[0.557]$} & & & {$[0.585]^{\star \star \star}$} \\
\hline moth & & & 0.804 & & & 1.176 & & & 0.597 & & & 1.336 \\
\hline monte & & & {$[0.380]^{\star *}$} & & & {$[0.510]^{\star \star}$} & & & {$[0.427]$} & & & {$[0.514]^{\star \star \star}$} \\
\hline father & & & -0.161 & & & -0.951 & & & -1.586 & & & -1.009 \\
\hline Iatrel working & & & {$[0.802]$} & & & [1.101] & & & [1.000] & & & [1.091] \\
\hline Observations & 4171 & 4171 & 3917 & 4174 & 4174 & 3920 & 4171 & 4171 & 3917 & 4174 & 4174 & 3920 \\
\hline R-squared & 0.42 & 0.5 & 0.5 & 0.39 & 0.51 & 0.51 & 0.26 & 0.51 & 0.52 & 0.28 & 0.47 & 0.48 \\
\hline
\end{tabular}

robust standard errors clustered at school level - constant and regional controls included

* significant at 10\%; ** significant at 5\%; *** significant at $1 \%$

\subsection{Discussion}

In this section we discuss a couple of methodological choices we made to evaluate the program and the main results emerging from the analysis.

On designing the impact evaluation we chose to select control classes in the same schools included in the program instead of choosing them in other schools. The trade-off is the one described in 
section 2: our design is at risk of contamination, the alternative one is at risk of selection bias. Overall, we still believe the choice we made is preferable. First of all because unless random assignment is feasible it is hard to control for across school differences based on the available information. Secondly, while it is hard to speculate on the sign of the bias due to selection it is intuitive that contamination induces a downward bias in the estimated causal effect. In the end, we believe that our estimate is a credible lower bound on the causal effect of $\mathrm{Cl} @$ ssi 2.0. Moreover, given the evidence in Table 4 on the size of the contamination problem, we believe the downward bias in our estimates should not be particularly large.

However, it should be clear to anyone willing to replicate our design that careful monitoring on the field enforcement of the rule - excluding the control class from the use of the ICT assigned to the treatment class - is essential to the validity of the design.

The second issue is about the choice of the test score measure. If we are to use the official test score measure provided by the Ministerial agency (Invalsi) we find a small statistically significant positive effect of ICT on student achievements, especially for children from uneducated parents, who are also likely to be at the bottom of the initial distribution of ability. These effects are still visible - albeit smaller ${ }^{14}$ - in the original test score measure. The algorithm used by Invalsi to predict potential cheating affect the distribution of test scores by compressing it towards the bottom (Angrist et al. 2014). ${ }^{15}$ In both cases, what matters is that the ICT impact on learning is low - and confined to the literacy score only for pupils in the bottom tail of the distribution - under both alternative measures, and this works against the effectiveness of money spent in equipments.

As for the substantive results, two main findings emerge forcefully: the impact of the program on student achievement as measured by the test scores in literacy and numeracy - if any - is confined to the bottom tail of the distribution and to the literacy score. There is no sign of an impact on the numeracy score and on the distribution of the literacy score away from the lower tail. A possible interpretation of these findings is in the report by the external observer who visited $40 \mathrm{Cl} @$ ssi 2.0 schools during the last year of the program (Dec. 2011 - Jan. 2012). He had access to all the documents, whether official or for internal use, produced by the schools to implement the program; he met the principals of the schools and all the teachers involved in the program discussing in depth with them on what they did, on what they have seen happening in the class, on what they perceived as the impact of the program on students behaviour and achievement; finally, he visited all the treated classes during a regular teaching hour. The result of his work is in a detailed report (in Italian, available on request).

There is a bunch of summary statements in the report providing clues to interpret our findings. First of all, the observed degree of cooperation between students in the $\mathrm{Cl} @$ ssi 2.0 is much stronger than in the standard classes: this is likely to result in a net gain for the weakest part of the class (disabled, immigrant and other weaker students). The external observer noted that the trigger activating this cooperation might have been a stronger commitment on the students side to perform 'a good job' along with the awareness that when the task is rather complex doing a good job requires a great deal of cooperation between all those involved.

\footnotetext{
${ }^{14}$ A possible explanation for the larger effect we found using the official Invalsi score is that the probability of cheating turns out to be smaller for treated classes (including in the regression a full set of controls at the class level) for literacy while there is no statistically significant difference between treated and control classes for numeracy (results available from the authors). Therefore, the Invalsi correction for cheating produces a larger estimated effect on the literacy score.

${ }^{15}$ If we run the regressions reported in tables A.3 and A.4 replacing class mean test scores with class standard deviation of the same test, we do not find reduction in dispersion of test scores caused by the ICT acquisition, irrespective of whether one uses original or corrected test scores. Available from the authors.
} 
All Cl@ssi 2.0 teachers stress that what they did with disabled students would not have been possible in a standard class. There is also a widespread agreement on judging Cl@ssi 2.0 as a powerful tool to the integration of foreign students. Finally, teachers' perception of the benefit stemming from the program is particularly strong in schools located in socially deprived areas.

According to the interviews to the teachers in the treated classes, the ICT available to the Cl@ssi 2.0 is an extremely powerful tool to enhance the effectiveness of the traditional way of teaching, for it allows integrating together words, images, sounds in a stable reservoir easily and readily available to all students. Again, the weakest part of the class is likely to benefit the most from this since better students would be able to find their way to learning even in the standard scenario possibly exploiting the resources they have available at home.

To exploit the potential of ICT enhanced teaching requires more intense interactions between teachers and students as compared to standard teaching practices. This may explain why there is some evidence of a significant - albeit small - impact on literacy and not in numeracy: in the Italian junior high school teachers of Language and Literature spend 12 hours per week in the same class (not to say that in most instances they are also in charge of teaching History and Geography) as compared to teachers of Math and Science, who typically spend 4 hours per week.

\section{Concluding remarks}

This paper represents one of the first counterfactual evaluation of the effect of ICT resources at school on student achievements conducted in Italy. Despite the huge investment of resources (in the order of 1500 Euros per student over a three year period), results are almost negligible. Even if we take the most encouraging results (see columns 3 or 4 of table 11), the average improvement associated to the programme would be 3 test points, corresponding to $17 \%$ of a standard deviation. Any cost-benefit evaluation would question the effectiveness of a programme costing 10.000 Euros for each test point of improvement.

We have suggested that this represents a lower bound estimates of the real effect, given the potential contamination between treatment and control classes. But the available evidence points to a low degree of contamination hence to a small negative bias - if any - in our estimate. Our estimates have also to confront with the problem of cheating, since they are statistically more significant when we make reference to test scores corrected for cheating which is likely due to the collateral evidence we have that treated classes are less likely to cheat.

Overall this leaves open the issue why interviewed teachers are strongly convinced of the positive effect of ICT adoption, while recorded impact on achievement is at best weak. One possible interpretation is that teachers possess a wider and more complex view on students engagement in learning activity. This would require additional long-run outcomes. One should explore the consequence of being exposed to ICT on the following years outcomes, where conditional on passing the final exam concluding lower secondary (licenza media) students have to choose among three alternative tracks: academic, technical or vocational. We intend to proceed in this line of research, collecting further information of subsequent step of their careers. 


\section{References}

Angrist, J., and V. Lavy. 2002. New Evidence on Classroom Computers and Pupil Learning. Economic Journal 112: 735-765.

Angrist, J., E.Battistin and D.Vuri. 2014. In a Small Moment: Cheating and Class Size in Italian Primary Schools. NBER wp. 20173

Balanskat, Anja, Roger Blamire and Stella Kefala. 2006. The ICT Impact Report. A review of studies of ICT impact on schools in Europe. European Schoolnet

Barrera-Osorio, Felipe, and Leigh L. Linden. 2009. The Use and Misuse of Computers in Education: Evidence from a Randomized Experiment in Colombia. Policy Research Working Paper 4836, Impact Evaluation Series No. 29, The World Bank.

Barrow, Lisa, Lisa Markman, and Cecilia E. Rouse. 2009. Technology's Edge: The Educational Benefits of Computer-Aided Instruction. American Economic Journal: Economic Policy, 1(1): 52-74

Bertoni, Marco, Brunello, Giorgio and Rocco, Lorenzo. 2013. When the cat is near, the mice won't play: the effect of external examiners in Italian schools. Journal of Public Economics, 104, pp. $65-77$

Beuermann, Diether W., Julian P. Cristia, Yyannu Cruz-Aguayo, Santiago Cueto and Ofer Malamud. 2013. Home computers and child outcomes: short-term impacts from a randomized experiment in Peru. NBER wp. 18818

Cristia, Julian P., Pablo Ibarraran, Santiago Cueto, Ana Santiago, and Eugenio Severin. 2012. Technology and Child Development: Evidence from the One Laptop per Child Program. Inter-American Development Bank Working Paper No. IDB-WP-304.

Eurydice 2011. Key data on Learning and Innovation through ICT at school in Europe 2011. Brussels

Fairlie, Robert and Jonathan Robinson. 2013. Experimental Evidence on the Effects of Home Computers on Academic Achievement among Schoolchildren. UC Santa Cruz working paper series

Fairlie, Robert and Rebecca London. 2012. The Effects of Home Computers on Educational Outcomes: Evidence from a Field Experiment with Community College Students. Economic Journal 122(June): 727-753

Ferrando, Mery, Alina Machado, Ivone Perazzo and Adriana Vernengo. 2012. Impact Assessment of the First OLPC National Model: The Uruguayan Plan Ceibal. mimeo

Goolsbee, Austan, and Jonathan Guryan. 2006. The Impact of Internet Subsidies in Public Schools. The Review of Economics and Statistics 88(2): 336-347.

Hyland, Marie; Layte, Richard; Lyons, Sean; McCoy, Selina; Silles, Mary. 2013. Are classroom internet use and academic performance higher after government broadband subsidies to primary schools?. 2013 mimeo

Machin, Stephen, Sandra McNally, and Olmo Silva. 2007. New Technology in Schools: Is There a Payoff?. Economic Journal, 117(522): 1145-1167, July.

Quintano, C., R. Castellano and S. Longobardi. 2009. A Fuzzy Clustering Approach to Improve the Accuracy of Italian Student Data. An Experimental Procedure to Correct the Impact of the Outliers on Assessment Test Scores. Statistica \& Applicazioni ,Vol.VII(2),149-17

Vigdor, Jacob L., and Helen F. Ladd. 2010. Scaling the Digital Divide: Home Computer Technology and Student Achievement. NBER Working Paper No. 16078

White, Howard. 2010. A Contribution to Current Debates in Impact. Evaluation 16: 153-164 


\section{Appendix}

Table A.1 - Descriptive statistics of the entire sample

\begin{tabular}{|c|c|c|c|c|c|}
\hline Variable & Obs & Mean & Std. Dev. & Min & Max \\
\hline treatment & 6744 & 0.51 & 0.50 & 0 & 1 \\
\hline female & 6744 & 0.47 & 0.50 & 0 & 1 \\
\hline birth year & 6731 & 97.90 & 2.35 & 9 & 99 \\
\hline foreign born & 6744 & 0.07 & 0.26 & 0 & 1 \\
\hline disable & 6744 & 0.03 & 0.18 & 0 & 1 \\
\hline at least one parent with college & 5680 & 0.31 & 0.46 & 0 & 1 \\
\hline Italian spoken at home & 6105 & 0.77 & 0.42 & 0 & 1 \\
\hline number of books at home & 6091 & 2.89 & 1.23 & 1 & 5 \\
\hline number of siblings & 6189 & 1.26 & 0.91 & 0 & 4 \\
\hline two parent & 6160 & 0.86 & 0.35 & 0 & 1 \\
\hline mother working & 6025 & 0.70 & 0.46 & 0 & 1 \\
\hline father working & 6002 & 0.96 & 0.20 & 0 & 1 \\
\hline test score Mathematics - Nov 2009 - 6th grade & 6007 & 56.28 & 16.17 & 0.00 & 100 \\
\hline test score Mathematics - June 2012 - 8th grade - original & 4880 & 56.73 & 17.41 & 10.87 & 100 \\
\hline test score Mathematics - June 2012 - 8th grade - corrected for cheating & 4880 & 52.24 & 17.13 & 4.84 & 100 \\
\hline test score Italian - Nov 2009 - 6th grade & 5978 & 65.00 & 15.15 & 0.00 & 100 \\
\hline test score Italian - June 2012 - 8th grade - original & 4862 & 75.31 & 13.09 & 12.94 & 100 \\
\hline test score Italian - June 2012 - 8th grade - corrected for cheating & 4880 & 69.39 & 17.15 & 0.00 & 100 \\
\hline
\end{tabular}

Table A.2: Probability of taking the test in $6^{\text {th }}$ grade (November 2009)

\begin{tabular}{|l|c|c|c|}
\hline & 1 & 2 & 3 \\
\hline & $\begin{array}{c}\text { linear } \\
\text { probability }\end{array}$ & $\begin{array}{c}\text { linear } \\
\text { probability }\end{array}$ & $\begin{array}{c}\text { linear } \\
\text { probability }\end{array}$ \\
\hline $\begin{array}{l}\text { Dependent variable: } \\
\text { taking the test (fraction of students) }\end{array}$ & $89.21 \%$ & $97.38 \%$ & $97.57 \%$ \\
\hline female & 0.014 & 0.013 & 0.014 \\
\hline & {$[0.007]^{\star}$} & {$[0.004]^{\star \star \star}$} & {$[0.004]^{\star \star \star}$} \\
\hline birth year & 0.006 & 0.003 & 0.003 \\
\hline & {$[0.003]^{\star}$} & {$[0.002]$} & {$[0.002]$} \\
\hline foreign born & -0.013 & 0.017 & 0.024 \\
\hline & {$[0.016]$} & {$[0.008]^{\star \star}$} & {$[0.007]^{\star \star \star}$} \\
\hline at least one parent with college & & -0.003 & -0.002 \\
\hline & & {$[0.005]$} & {$[0.005]$} \\
\hline Italian spoken at home & & -0.003 & -0.004 \\
\hline & & {$[0.006]$} & {$[0.006]$} \\
\hline number of books at home & & 0.007 & 0.005 \\
\hline & & {$[0.002]^{\star \star \star}$} & {$[0.002]^{\star \star}$} \\
\hline number of siblings & & & -0.005 \\
\hline & & & {$[0.003]$} \\
\hline two parent & & & 0.01 \\
\hline & & & {$[0.008]$} \\
\hline mother working & & & 0.004 \\
\hline & & & {$[0.005]$} \\
\hline father working & & & 0.023 \\
\hline & & & {$[0.016]$} \\
\hline Observations & 6731 & 5533 & 5263 \\
\hline Pseudo R & 0.01 & 0.01 & 0.02 \\
\hline
\end{tabular}

Robust standard errors in brackets

* significant at $10 \%$; ** significant at $5 \%$; *** significant at $1 \%$

standard errors in brackets clustered at school level - region controls included 
Table A.3: The effect of the treatment Cl@ssi2.0 on test scores at $8^{\text {th }}$ grade (original test scores) class averages.

\begin{tabular}{|c|c|c|c|c|c|c|c|c|}
\hline \multirow[t]{2}{*}{ original test scores } & \multicolumn{4}{|c|}{ Literacy } & \multicolumn{4}{|c|}{ numeracy } \\
\hline & 1 & 2 & 3 & 4 & 5 & 6 & 7 & 8 \\
\hline & basic & extended & $\begin{array}{l}\text { extended } \\
\text { school } \\
\text { FE }\end{array}$ & $\begin{array}{l}\text { extended } \\
\text { school FE }\end{array}$ & basic & extended & $\begin{array}{l}\text { extended } \\
\text { school } \\
\text { FE }\end{array}$ & $\begin{array}{l}\text { extended } \\
\text { school } \\
\text { FE }\end{array}$ \\
\hline \multirow{2}{*}{$\begin{array}{l}\text { test score at entrance ( } 6^{\text {th }} \text { grade - } \\
\text { class average) }\end{array}$} & 0.415 & 0.299 & 0.408 & 0.387 & 0.419 & 0.397 & 0.355 & 0.335 \\
\hline & {$[0.095]^{\star \star \star}$} & {$[0.099]^{\star \star \star}$} & {$[0.083]^{\star \star \star}$} & {$[0.080]^{\star \star \star}$} & {$[0.088]^{\star \star \star}$} & {$[0.125]^{\star \star \star}$} & {$[0.152]^{\star \star}$} & {$[0.154]^{\star \star}$} \\
\hline \multirow[t]{2}{*}{ treated class } & 0.333 & 0.455 & 0.262 & 1.858 & -0.13 & -0.248 & -0.053 & 1.618 \\
\hline & {$[0.643]$} & {$[0.628]$} & [0.503] & [1.199] & [1.058] & [1.067] & [1.003] & {$[2.005]$} \\
\hline \multirow[t]{2}{*}{ probability of cheating (estimated) } & 18.009 & 17.749 & 11.754 & 12.468 & 40.719 & 36.75 & 29.166 & 29.359 \\
\hline & {$[2.311]^{\star \star \star}$} & {$[2.273]^{\star \star \star}$} & {$[1.622]^{\star \star \star}$} & {$[1.658]^{\star \star \star}$} & {$[3.749]^{\star \star \star}$} & {$[3.872]^{\star \star \star}$} & {$[7.008]^{\star \star \star}$} & {$[7.103]^{\star \star \star}$} \\
\hline \multirow[t]{2}{*}{ girls (share) } & & 3.687 & 0.852 & 0.87 & & 0.146 & -1.452 & -1.641 \\
\hline & & [2.560] & [2.976] & [2.873] & & {$[4.170]$} & [5.706] & [5.700] \\
\hline \multirow[t]{2}{*}{ birth year (class average) } & & -2.822 & -2.336 & -2.578 & & -0.182 & -2.169 & -2.329 \\
\hline & & [3.146] & [4.116] & {$[4.048]$} & & [5.564] & [7.955] & [8.005] \\
\hline \multirow[t]{2}{*}{ foreign born (share) } & & -5.447 & -4.787 & -4.397 & & -12.421 & -3.019 & -2.445 \\
\hline & & [3.797] & [6.546] & [6.503] & & {$[7.143]^{\star}$} & [18.231] & {$[18.466]$} \\
\hline \multirow{2}{*}{$\begin{array}{l}\text { at least one college graduate parent } \\
\text { (share) }\end{array}$} & & 8.334 & 8.017 & 10.938 & & 5.994 & 6.631 & 9.76 \\
\hline & & {$[2.211]^{\star \star \star}$} & {$[2.692]^{\star \star \star}$} & {$[3.187]^{\star \star \star}$} & & {$[3.491]^{\star}$} & [5.691] & [6.490] \\
\hline \multirow{2}{*}{$\begin{array}{l}\text { at least one college graduate } \\
\text { parent (share) } \times \text { treated class }\end{array}$} & & & & -5.081 & & & & -5.38 \\
\hline & & & & [3.130] & & & & [4.959] \\
\hline \multirow{2}{*}{$\begin{array}{l}\text { fraction of permanent teachers (still } \\
\text { in the school after } 3 \text { years) }\end{array}$} & & 1.464 & 2.003 & 1.573 & & 4.789 & 2.339 & 2.013 \\
\hline & & [2.106] & [3.120] & [3.131] & & [3.495] & [5.595] & {$[5.594]$} \\
\hline Observations & 268 & 268 & 268 & 268 & 268 & 268 & 268 & 268 \\
\hline $\mathrm{R}^{2}$ & 0.48 & 0.52 & 0.83 & 0.83 & 0.42 & 0.48 & 0.78 & 0.79 \\
\hline
\end{tabular}

robust standard errors clustered at school level - constant and regional controls included

* significant at $10 \%$; ** significant at $5 \%$; ${ }^{* \star *}$ significant at $1 \%$

Table A.4: The effect of the treatment Cl@ssi2.0 on test scores at $8^{\text {th }}$ grade (test scores corrected for cheating by Invalsi) - class averages.

\begin{tabular}{|c|c|c|c|c|c|c|c|c|}
\hline \multirow[t]{2}{*}{ corrected test scores } & \multicolumn{4}{|c|}{ Literacy } & \multicolumn{4}{|c|}{ numeracy } \\
\hline & 1 & 2 & 3 & 4 & 5 & 6 & 7 & 8 \\
\hline & basic & extended & $\begin{array}{c}\text { extended } \\
\text { school } \\
\text { FE }\end{array}$ & $\begin{array}{l}\text { extended } \\
\text { school FE }\end{array}$ & basic & extended & $\begin{array}{c}\text { extended } \\
\text { school } \\
\text { FE }\end{array}$ & $\begin{array}{c}\text { extended } \\
\text { school } \\
\text { FE }\end{array}$ \\
\hline \multirow{2}{*}{$\begin{array}{l}\text { test score at entrance }\left(6^{\text {th }} \text { grade - }\right. \\
\text { class average) }\end{array}$} & 0.043 & -0.034 & 0.281 & 0.202 & 0.536 & 0.397 & 0.324 & 0.297 \\
\hline & {$[0.123]$} & [0.131] & [0.195] & {$[0.194]$} & {$[0.101]^{\star \star \star}$} & {$[0.155]^{\star \star}$} & {$[0.189]^{\star}$} & [0.186] \\
\hline \multirow[t]{2}{*}{ treated class } & 1.622 & 1.935 & 1.948 & 8.084 & -0.38 & -0.318 & -0.064 & 2.083 \\
\hline & [1.437] & [1.461] & {$[1.371]$} & {$[3.077]^{\star \star \star}$} & {$[1.302]$} & [1.359] & [1.335] & {$[2.480]$} \\
\hline \multirow[t]{2}{*}{ girls (share) } & & 0.038 & 9.39 & 8.919 & & 2.625 & 4.849 & 4.513 \\
\hline & & {$[5.126]$} & [8.521] & [8.018] & & [4.902] & [6.355] & [6.421] \\
\hline \multirow[t]{2}{*}{ birth year (class average) } & & -0.087 & 1.3 & 1.852 & & 0.095 & -2.926 & -2.741 \\
\hline & & [1.451] & [1.214] & [1.153] & & [1.773] & {$[1.478]^{\star \star}$} & {$[1.486]^{\star}$} \\
\hline \multirow[t]{2}{*}{ foreign born (share) } & & 2.425 & -0.182 & 1.958 & & -8.748 & 1.311 & 2.237 \\
\hline & & [6.784] & {$[11.643]$} & [11.636] & & [6.931] & {$[16.916]$} & [17.082] \\
\hline \multirow{2}{*}{$\begin{array}{l}\text { at least one college graduate parent } \\
\text { (share) }\end{array}$} & & 8.032 & 7.857 & 19.064 & & 6.584 & 7.817 & 11.796 \\
\hline & & {$[4.658]^{\star}$} & {$[5.422]$} & {$[8.130]^{\star \star}$} & & [4.937] & [8.577] & [8.952] \\
\hline \multirow{2}{*}{$\begin{array}{l}\text { at least one college graduate } \\
\text { parent (share) } \times \text { treated class }\end{array}$} & & & & -19.654 & & & & -6.894 \\
\hline & & & & {$[8.543]^{\star *}$} & & & & {$[5.621]$} \\
\hline \multirow{2}{*}{$\begin{array}{l}\text { fraction of permanent teachers (still } \\
\text { in the school after } 3 \text { years) }\end{array}$} & & -4.164 & -10.029 & -11.297 & & 2.048 & -3.479 & -3.87 \\
\hline & & [4.542] & [7.937] & [7.738] & & [4.449] & [7.672] & [7.751] \\
\hline Observations & 268 & 268 & 268 & 268 & 268 & 268 & 268 & 268 \\
\hline$\overline{R^{2}}$ & 0.22 & 0.23 & 0.64 & 0.66 & 0.15 & 0.19 & 0.67 & 0.68 \\
\hline
\end{tabular}

robust standard errors clustered at school level - constant and regional controls included * significant at 10\%; ** significant at 5\%; *** significant at $1 \%$ 
Table A.5 - The effect of Cl@ssi2.0 on test scores at grade $8^{\text {th }}$ - quantile regression on individual student data (original and corrected literacy test scores)

\begin{tabular}{|c|c|c|c|c|c|c|c|c|c|}
\hline & & \multicolumn{4}{|c|}{ Literacy (original) } & \multicolumn{4}{|c|}{ Literacy (corrected) } \\
\hline & & Coef. & Std. Err. & $t$ & $\mathrm{P}>\mathrm{t}$ & Coef. & Std. Err. & $\mathrm{t}$ & $\mathrm{P}>\mathrm{t}$ \\
\hline \multirow[t]{5}{*}{$q 10$} & treatment & 0.42 & 0.63 & 0.68 & 0.50 & 6.84 & 1.54 & 4.44 & 0.00 \\
\hline & test score at entrance $\left(6^{\text {th }}\right.$ grade $)$ & 0.71 & 0.02 & 33.45 & 0.00 & 0.41 & 0.04 & 9.52 & 0.00 \\
\hline & one parent with college & 1.72 & 0.62 & 2.80 & 0.01 & 0.94 & 1.23 & 0.77 & 0.44 \\
\hline & fraction of permanent teachers & 4.99 & 1.66 & 3.00 & 0.00 & -1.58 & 2.78 & -0.57 & 0.57 \\
\hline & probability of cheating & 14.71 & 1.15 & 12.82 & 0.00 & & & & \\
\hline \multirow[t]{5}{*}{$q 20$} & treatment & 0.38 & 0.54 & 0.70 & 0.49 & 0.61 & 0.98 & 0.62 & 0.54 \\
\hline & test score at entrance $\left(6^{\text {th }}\right.$ grade $)$ & 0.66 & 0.02 & 34.03 & 0.00 & 0.58 & 0.03 & 22.53 & 0.00 \\
\hline & one parent with college & 2.35 & 0.47 & 4.96 & 0.00 & 0.99 & 1.03 & 0.96 & 0.34 \\
\hline & fraction of permanent teachers & 3.15 & 1.00 & 3.14 & 0.00 & 4.28 & 2.48 & 1.73 & 0.08 \\
\hline & probability of cheating & 12.68 & 1.27 & 9.99 & 0.00 & & & & \\
\hline \multirow[t]{5}{*}{ q30 } & treatment & -0.04 & 0.44 & -0.10 & 0.92 & 0.33 & 0.61 & 0.54 & 0.59 \\
\hline & test score at entrance $\left(6^{\text {th }}\right.$ grade $)$ & 0.61 & 0.01 & 43.08 & 0.00 & 0.58 & 0.02 & 31.57 & 0.00 \\
\hline & one parent with college & 1.85 & 0.43 & 4.31 & 0.00 & 1.60 & 0.54 & 2.98 & 0.00 \\
\hline & fraction of permanent teachers & 2.43 & 1.19 & 2.05 & 0.04 & 3.72 & 1.38 & 2.69 & 0.01 \\
\hline & probability of cheating & 12.77 & 0.88 & 14.47 & 0.00 & & & & \\
\hline \multirow[t]{5}{*}{ q40 } & treatment & -0.30 & 0.36 & -0.83 & 0.40 & -0.35 & 0.50 & -0.69 & 0.49 \\
\hline & test score at entrance $\left(6^{\text {th }}\right.$ grade $)$ & 0.58 & 0.02 & 35.10 & 0.00 & 0.57 & 0.02 & 35.11 & 0.00 \\
\hline & one parent with college & 1.60 & 0.41 & 3.86 & 0.00 & 1.59 & 0.46 & 3.49 & 0.00 \\
\hline & fraction of permanent teachers & 0.74 & 0.99 & 0.74 & 0.46 & 2.04 & 1.31 & 1.56 & 0.12 \\
\hline & probability of cheating & 12.44 & 0.71 & 17.44 & 0.00 & & & & \\
\hline \multirow[t]{5}{*}{ q50 } & treatment & -0.25 & 0.35 & -0.72 & 0.47 & -0.50 & 0.42 & -1.18 & 0.24 \\
\hline & test score at entrance $\left(6^{\text {th }}\right.$ grade $)$ & 0.54 & 0.01 & 38.33 & 0.00 & 0.54 & 0.02 & 32.07 & 0.00 \\
\hline & one parent with college & 1.51 & 0.42 & 3.59 & 0.00 & 1.27 & 0.36 & 3.53 & 0.00 \\
\hline & fraction of permanent teachers & -0.16 & 0.88 & -0.18 & 0.85 & 1.08 & 1.07 & 1.01 & 0.31 \\
\hline & probability of cheating & 12.35 & 1.17 & 10.54 & 0.00 & & & & \\
\hline \multirow[t]{5}{*}{$q 60$} & treatment & -0.30 & 0.30 & -0.99 & 0.32 & -0.24 & 0.41 & -0.58 & 0.56 \\
\hline & test score at entrance $\left(6^{\text {th }}\right.$ grade $)$ & 0.49 & 0.02 & 29.96 & 0.00 & 0.52 & 0.02 & 31.81 & 0.00 \\
\hline & one parent with college & 1.76 & 0.41 & 4.26 & 0.00 & 1.45 & 0.45 & 3.24 & 0.00 \\
\hline & fraction of permanent teachers & -1.30 & 0.96 & -1.35 & 0.18 & 0.84 & 1.00 & 0.83 & 0.40 \\
\hline & probability of cheating & 11.88 & 0.83 & 14.32 & 0.00 & & & & \\
\hline \multirow[t]{5}{*}{ q70 } & treatment & -0.42 & 0.34 & -1.25 & 0.21 & -0.32 & 0.39 & -0.83 & 0.40 \\
\hline & test score at entrance $\left(6^{\text {th }}\right.$ grade $)$ & 0.45 & 0.02 & 28.11 & 0.00 & 0.46 & 0.02 & 26.71 & 0.00 \\
\hline & one parent with college & 1.61 & 0.41 & 3.93 & 0.00 & 1.37 & 0.40 & 3.38 & 0.00 \\
\hline & fraction of permanent teachers & -0.31 & 0.78 & -0.40 & 0.69 & -0.31 & 1.07 & -0.29 & 0.77 \\
\hline & probability of cheating & 11.33 & 1.12 & 10.14 & 0.00 & & & & \\
\hline \multirow[t]{5}{*}{ q80 } & treatment & -0.40 & 0.33 & -1.22 & 0.22 & -0.45 & 0.32 & -1.41 & 0.16 \\
\hline & test score at entrance $\left(6^{\text {th }}\right.$ grade $)$ & 0.40 & 0.02 & 26.02 & 0.00 & 0.43 & 0.01 & 32.02 & 0.00 \\
\hline & one parent with college & 1.19 & 0.41 & 2.87 & 0.00 & 1.14 & 0.36 & 3.19 & 0.00 \\
\hline & fraction of permanent teachers & -0.22 & 0.88 & -0.25 & 0.81 & 0.84 & 0.83 & 1.02 & 0.31 \\
\hline & probability of cheating & 11.50 & 0.96 & 11.95 & 0.00 & & & & \\
\hline \multirow[t]{5}{*}{ q90 } & treatment & -0.05 & 0.34 & -0.16 & 0.88 & -0.53 & 0.36 & -1.48 & 0.14 \\
\hline & test score at entrance $\left(6^{\text {th }}\right.$ grade $)$ & 0.33 & 0.02 & 21.85 & 0.00 & 0.38 & 0.02 & 20.39 & 0.00 \\
\hline & one parent with college & 1.11 & 0.41 & 2.72 & 0.01 & 1.14 & 0.46 & 2.46 & 0.01 \\
\hline & fraction of permanent teachers & 0.46 & 0.66 & 0.70 & 0.48 & 1.84 & 1.36 & 1.35 & 0.18 \\
\hline & probability of cheating & 12.21 & 1.57 & 7.78 & 0.00 & & & & \\
\hline
\end{tabular}

Quantile regressions include as additional regressors: gender, birth year and foreign born

* significant at 10\%; ** significant at 5\%; *** significant at $1 \%-50$ replications 
Table A.6 - The effect of Cl@ssi2.0 on test scores at grade $8^{\text {th }}$ - quantile regression on individual student data (original and corrected numeracy test scores)

\begin{tabular}{|c|c|c|c|c|c|c|c|c|c|}
\hline & & \multicolumn{4}{|c|}{ Numeracy (original) } & \multicolumn{4}{|c|}{ Numeracy (corrected) } \\
\hline & & Coef. & Std. Err. & $t$ & $\mathrm{P}>\mathrm{t}$ & Coef. & Std. Err. & $\mathrm{t}$ & $\mathrm{P}>\mathrm{t}$ \\
\hline \multirow[t]{5}{*}{$\mathrm{q} 10$} & treatment & -0.14 & 0.79 & -0.18 & 0.86 & -0.06 & 0.89 & -0.06 & 0.95 \\
\hline & test score at entrance $\left(6^{\text {th }}\right.$ grade $)$ & 0.52 & 0.03 & 19.32 & 0.00 & 0.57 & 0.03 & 16.80 & 0.00 \\
\hline & one parent with college & 1.46 & 0.96 & 1.53 & 0.13 & -0.72 & 1.23 & -0.59 & 0.56 \\
\hline & fraction of permanent teachers & 2.96 & 1.81 & 1.64 & 0.10 & -1.94 & 2.21 & -0.88 & 0.38 \\
\hline & probability of cheating & 42.18 & 1.67 & 25.24 & 0.00 & & & & \\
\hline \multirow[t]{5}{*}{$q 20$} & treatment & -0.05 & 0.57 & -0.09 & 0.93 & -1.68 & 0.87 & -1.92 & 0.06 \\
\hline & test score at entrance $\left(6^{\text {th }}\right.$ grade $)$ & 0.55 & 0.02 & 33.79 & 0.00 & 0.60 & 0.02 & 26.29 & 0.00 \\
\hline & one parent with college & 2.63 & 0.79 & 3.33 & 0.00 & 1.71 & 0.99 & 1.73 & 0.09 \\
\hline & fraction of permanent teachers & 4.25 & 1.81 & 2.35 & 0.02 & 4.05 & 2.16 & 1.87 & 0.06 \\
\hline & probability of cheating & 41.97 & 1.52 & 27.60 & 0.00 & & & & \\
\hline \multirow[t]{5}{*}{ q30 } & treatment & -0.12 & 0.55 & -0.21 & 0.83 & -1.19 & 0.64 & -1.85 & 0.06 \\
\hline & test score at entrance $\left(6^{\text {th }}\right.$ grade $)$ & 0.57 & 0.02 & 31.60 & 0.00 & 0.59 & 0.03 & 21.80 & 0.00 \\
\hline & one parent with college & 3.17 & 0.60 & 5.24 & 0.00 & 3.20 & 0.85 & 3.76 & 0.00 \\
\hline & fraction of permanent teachers & 1.47 & 1.58 & 0.93 & 0.35 & 2.15 & 1.91 & 1.12 & 0.26 \\
\hline & probability of cheating & 41.30 & 1.37 & 30.14 & 0.00 & & & & \\
\hline \multirow[t]{5}{*}{ q40 } & treatment & -0.42 & 0.53 & -0.79 & 0.43 & -0.70 & 0.58 & -1.22 & 0.22 \\
\hline & test score at entrance $\left(6^{\text {th }}\right.$ grade $)$ & 0.59 & 0.02 & 34.49 & 0.00 & 0.60 & 0.02 & 29.95 & 0.00 \\
\hline & one parent with college & 3.03 & 0.67 & 4.50 & 0.00 & 3.22 & 0.73 & 4.39 & 0.00 \\
\hline & fraction of permanent teachers & -0.33 & 1.65 & -0.20 & 0.84 & 0.72 & 1.82 & 0.39 & 0.69 \\
\hline & probability of cheating & 41.87 & 1.38 & 30.35 & 0.00 & & & & \\
\hline \multirow[t]{5}{*}{ q50 } & treatment & -0.59 & 0.54 & -1.08 & 0.28 & -0.99 & 0.59 & -1.68 & 0.09 \\
\hline & test score at entrance $\left(6^{\text {th }}\right.$ grade $)$ & 0.55 & 0.02 & 31.30 & 0.00 & 0.58 & 0.02 & 33.99 & 0.00 \\
\hline & one parent with college & 3.12 & 0.62 & 5.02 & 0.00 & 3.52 & 0.64 & 5.54 & 0.00 \\
\hline & fraction of permanent teachers & 0.87 & 2.25 & 0.39 & 0.70 & 2.40 & 2.12 & 1.13 & 0.26 \\
\hline & probability of cheating & 40.36 & 1.74 & 23.23 & 0.00 & & & & \\
\hline \multirow[t]{5}{*}{$q 60$} & treatment & -1.11 & 0.53 & -2.08 & 0.04 & -1.10 & 0.60 & -1.84 & 0.07 \\
\hline & test score at entrance $\left(6^{\text {th }}\right.$ grade $)$ & 0.54 & 0.02 & 31.27 & 0.00 & 0.57 & 0.01 & 41.35 & 0.00 \\
\hline & one parent with college & 3.08 & 0.61 & 5.07 & 0.00 & 3.14 & 0.65 & 4.83 & 0.00 \\
\hline & fraction of permanent teachers & -0.89 & 1.78 & -0.50 & 0.62 & 2.65 & 1.97 & 1.34 & 0.18 \\
\hline & probability of cheating & 41.82 & 2.16 & 19.36 & 0.00 & & & & \\
\hline \multirow[t]{5}{*}{ q70 } & treatment & -0.57 & 0.55 & -1.04 & 0.30 & -0.56 & 0.60 & -0.93 & 0.35 \\
\hline & test score at entrance $\left(6^{\text {th }}\right.$ grade $)$ & 0.52 & 0.02 & 28.05 & 0.00 & 0.54 & 0.02 & 31.80 & 0.00 \\
\hline & one parent with college & 2.60 & 0.58 & 4.46 & 0.00 & 3.07 & 0.64 & 4.82 & 0.00 \\
\hline & fraction of permanent teachers & -0.03 & 1.73 & -0.02 & 0.99 & 2.59 & 1.68 & 1.54 & 0.12 \\
\hline & probability of cheating & 42.32 & 2.54 & 16.64 & 0.00 & & & & \\
\hline \multirow[t]{5}{*}{ q80 } & treatment & 0.20 & 0.60 & 0.33 & 0.74 & 0.28 & 7.15 & 0.04 & 0.97 \\
\hline & test score at entrance $\left(6^{\text {th }}\right.$ grade $)$ & 0.50 & 0.02 & 27.86 & 0.00 & 0.53 & 0.08 & 6.59 & 0.00 \\
\hline & one parent with college & 1.82 & 0.61 & 2.98 & 0.00 & 2.62 & 11.51 & 0.23 & 0.82 \\
\hline & fraction of permanent teachers & 2.53 & 1.96 & 1.29 & 0.20 & 4.75 & 12.04 & 0.39 & 0.69 \\
\hline & probability of cheating & 43.12 & 2.56 & 16.83 & 0.00 & & & & \\
\hline \multirow[t]{5}{*}{ q90 } & treatment & 0.13 & 0.77 & 0.17 & 0.87 & 0.86 & 0.78 & 1.11 & 0.27 \\
\hline & test score at entrance $\left(6^{\text {th }}\right.$ grade $)$ & 0.44 & 0.02 & 21.72 & 0.00 & 0.47 & 0.02 & 21.75 & 0.00 \\
\hline & one parent with college & 1.91 & 0.85 & 2.24 & 0.03 & 2.30 & 0.62 & 3.73 & 0.00 \\
\hline & fraction of permanent teachers & 1.36 & 1.95 & 0.70 & 0.49 & 3.49 & 1.84 & 1.89 & 0.06 \\
\hline & probability of cheating & 46.04 & 3.87 & 11.90 & 0.00 & & & & \\
\hline
\end{tabular}

Quantile regressions include as additional regressors: gender, birth year and foreign born

* significant at 10\%; ** significant at 5\%; *** significant at $1 \%-50$ replications 